\title{
Anorden
}

\section{Building engagement and healthy organisations}

Validation of the Nordic Questionnaire on Positive Organisational Psychology (N-POP). The Third Report from the Nordic Project 

4 norden 



\section{Building engagement and healthy organisations}

Validation of the Nordic Questionnaire on Positive Organisational Psychology (N-POP). The Third Report from the Nordic Project

Marit Christensen, Gunnar Aronsson, Vilhelm Borg, Thomas Clausen, Johan Guthenberg, Jari Hakanen, Ulrika Lundberg \& Lisa Vivoll Straume 
Building engagement and healthy organisations

Validation of the Nordic Questionnaire on Positive Organisational Psychology (N-POP).

The Third Report from the Nordic Project

Marit Christensen, Gunnar Aronsson, Vilhelm Borg, Thomas Clausen, Johan Guthenberg,

Jari Hakanen Ulrika Lundberg \& Lisa Vivoll Straume

ISBN 978-92-893-2397-0

http://dx.doi.org/10.6027/TN2012-549

TemaNord 2012:549

(C) Nordic Council of Ministers 2012

Layout: Hanne Lebech

Cover photo: Image Select

Print: Rosendahl-Schultz Grafisk

Copies: 150

Printed in Denmark

This publication has been published with financial support by the Nordic Council of Ministers. However, the contents of this publication do not necessarily reflect the views, policies or recommendations of the Nordic Council of Ministers.

www.norden.org/en/publications

\section{Nordic co-operation}

Nordic co-operation is one of the world's most extensive forms of regional collaboration, involving Denmark, Finland, Iceland, Norway, Sweden, and the Faroe Islands, Greenland, and Åland.

Nordic co-operation has firm traditions in politics, the economy, and culture. It plays an important role in European and international collaboration, and aims at creating a strong Nordic community in a strong Europe.

Nordic co-operation seeks to safeguard Nordic and regional interests and principles in the global community. Common Nordic values help the region solidify its position as one of the world's most innovative and competitive.

\section{Nordic Council of Ministers}

Ved Stranden 18

DK-1061 Copenhagen $\mathrm{K}$

Phone (+45) 33960200

www.norden.org 


\section{Content}

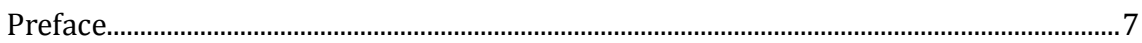

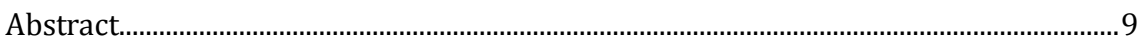

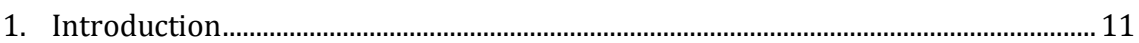

1.1 The case for positive work and organisational psychology .......................... 11

1.2 Positive psychology as a response to the challenges ahead........................... 12

1.3 Positive psychology and healthy organisations................................................ 13

1.4 Aims of the project and the report................................................................... 14

1.5 Conceptual framework ......................................................................................... 14

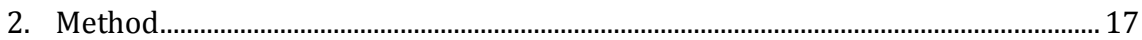

2.1 Sweden: Participants and procedure ............................................................... 17

2.2 Norway: Participants and procedure ................................................................. 17

2.3 Description of respondents in Sweden and Norway .................................... 18

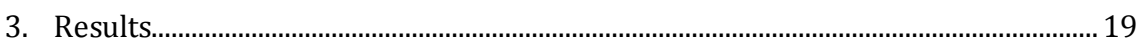

3.1 Internal consistency of the scales.................................................................. 19

3.2 Intercorrelations between the measures........................................................... 20

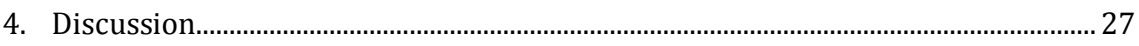

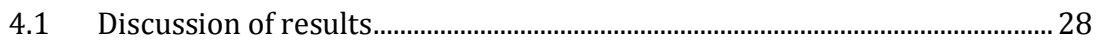

4.2 When to use the N-POP ..................................................................................... 30

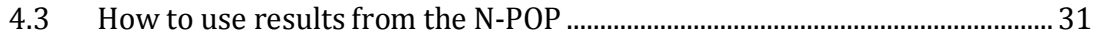

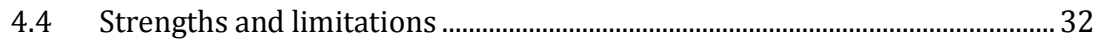

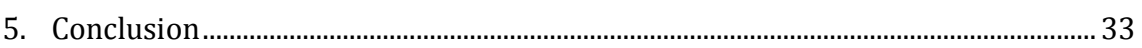

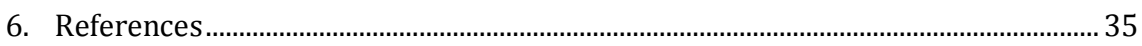

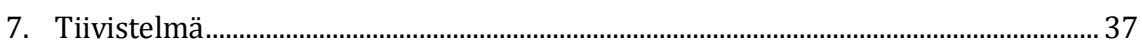

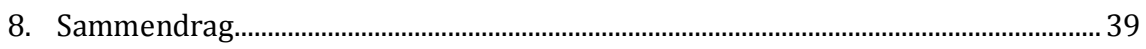

9. Appendix A. Descriptions of concepts underlying the scales

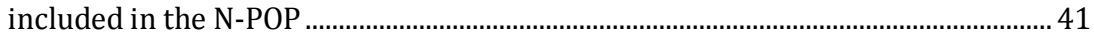

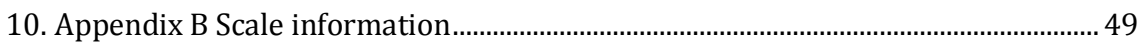

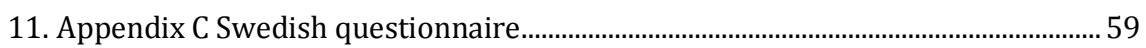

12. Appendix D Norwegian questionnaire.................................................................. 75 



\section{Preface}

The Nordic project "Building engagement and healthy organisations" started in 2009, building on results from the previous Nordic project "Positive factors at work". Both projects have been financed by the Nordic Council of Ministers. The current project is based on collaboration between researchers from four different Nordic countries: Denmark (National Research Centre for the Working Environment in Denmark (NRCWE)), Finland (Finnish Institute of Occupational Health), Norway (Department of Psychology, NTNU) and Sweden (Department of Psychology, Stockholm University).

The main aim has been to investigate the predictors of positive workrelated states and attitudes, e.g. work engagement, meaning at work and personal growth, and healthy organisations. We have worked on the assumption that work-life quality, organisational health, and productivity can and should be improved simultaneously. Building genuinely positive employee well-being characterised by, for example, engagement and a strong sense of meaning at work, together with fostering organisational resources and healthy practices, will also benefit the innovativeness and success of organisations.

The first project, "Positive factors at work" began in 2006. Two reports were published during the course of the project and this material has constituted background for the research presented in the current report. In the project "Building engagement and healthy organisations" we first developed and designed a questionnaire to measure positive factors at work, individual well-being and positive organisational performance. Further, we pilot-tested the questionnaire through data collections in chosen companies in Norway and Sweden. The results of these studies were used as a basis for a preliminary validation of the Nordic Questionnaire on Positive Organisational Psychology (N-POP) published in this report.

We would like to express our gratitude to the respondents who agreed to be part of the two studies in Norway and Sweden. We are extremely grateful for your response, feedback and interest in this field of research. Use of the questionnaire (N-POP) by both researchers and practitioners in the field is encouraged. Quality assurance through validation in future studies is a further aspiration. 



\section{Abstract}

This report is based on the results of the project "Building engagement and healthy organisations" financed by the Nordic Council of Ministers.

The main aim of the project was to investigate the predictors of positive work-related states and attitudes, e.g. work engagement, meaning at work and personal growth, and healthy organisations. In the first year of the project we developed and designed a questionnaire in order to measure positive factors at work, individual well-being and positive organisational performance. The questionnaire has been translated into both Norwegian and Swedish. In the second year of the project we planned and pilot-tested the questionnaire through data collection in chosen companies in Norway and Sweden. The Swedish participants were employed in a medium-sized bank and worked within financial services and within departments such as private marketing, development and administration ( $\mathrm{N}=180)$. The Norwegian questionnaire was distributed to eight different workplaces. These eight workplaces were categorised into three different categories: accounting/revision $(n=44)$, hospitals $(n=69)$, and university college $(n=89)$. The total Norwegian sample consisted of 202 respondents. The results of these studies were used as a base for a preliminary validation of the Nordic Questionnaire on Positive Organisational Psychology (N-POP) published in this report.

The introduction provides a theoretical foundation for the development of the questionnaire. A description of a working model is included together with a more detailed description of the concepts involved in the questionnaire. The aims of the project are also referred to in more detail.

The method section describes the samples in Norway and Sweden used as a basis for the validation study. Both the sampling procedure and the respondents are described. The result section provides the results for the reliability of the different measures included in the questionnaire, and the intercorrelations between the measures representing the construct validity of the measures included in the N-POP instrument. In the discussion, the working model is a central part of the discussion, and it is concluded that the N-POP constitutes a reliable and valid instrument for assessing the psychosocial work environment, work-related states and attitudes and a series of organisational and individual outcomes in modern work organisations. In addition, the discussion section gives advice and information on when and how to use the instrument. The concluding summary suggests that the concepts of work environment, health and productivity do indeed seem able to flow together to reach an optimal point at which well-being at the individual level is coexistent with efficient and productive work organisations. 



\section{Introduction}

\subsection{The case for positive work and organisational psychology}

Nordic welfare societies are currently facing two major challenges. The first challenge stems from changes in the demographic composition of the Nordic countries (Nordic Council of Ministers, 2006, p. 61). These demographic changes may, in combination with widespread early retirement from the labour market (Nordic Council of Ministers, 2006, p. 109), result in a shortage of labour in the Nordic countries in the coming decades. The field of positive work and organisational psychology appears to offer some interesting insights in response to this challenge, as the knowledge generated might help to increase labour supply through its emphasis on building on factors related to intrinsic job motivation (Turner, Barling, \& Zacharatos, 2002). The issue of labour supply is traditionally approached in terms of establishing economic incentives but an alternative strategy towards increasing labour supply is offered by the field of positive work and organisational psychology (Clausen, 2009).

Another challenge that confronts the Nordic countries is related to the consequences of competition in an increasingly globalised economy. The dynamics of a globalised economy have helped to increase the workrelated demands experienced by large segments of the labour force. First, the pace of skill change and the frequency of organisational reorganisations have increased job insecurity. Second, the competitive pressure of a globalised economy and a tendency towards increased worker autonomy in the production process puts increased pressure on employees to perform (Esping Andersen, 2002; Wrzesniewski \& Dutton, 2001). Certainly, these developmental tendencies will have an impact on the well-being of employees in the contemporary labour market. Thus, in order to counter the increasingly stressful nature of contemporary work life (Ferrie et al., 2001) it appears crucial to focus on the development of a series of positive work-life resources that could increase employees' abilities to cope with work-related demands. 


\subsection{Positive psychology as a response to the challenges ahead}

Positive psychology may provide some interesting responses to the challenges confronting Nordic welfare societies. The school of positive psychology complements mainstream psychology and its focus is on creating a body of knowledge that focuses on human well-being and growth (e.g. Seligman \& Csikszentmihalyi, 2000).

From the perspective of positive psychology, concurrent experiences of positive affect are viewed as the fuel in processes that enhance individual and collective experiences of well-being, engagement and human growth (Frederickson \& Losada, 2005; Gable \& Haidt, 2005). According to Meyer and Allen (1997), experiences of positive affect are positively correlated with job performance whereas experiences of positive affect have been found to be negatively correlated with turnover intentions (see also Clausen \& Borg, 2010). Furthermore, research into the implications of positive experiences shows that experiences of positive affect are associated with creativity (Isen, Daubman, \& Nowicki, 1987) and intuition (Bolte, Goschkey, \& Kuhl, 2003). Also, Frederickson et al. have found that concurrent experiences of positive affect result in increases in individual resilience (Frederickson, Tugade, Waugh, \& Larkin, 2003). Experiences of positive affect at work have furthermore been found to increase the individual's capacity to cope with stress (Glazer \& Kruse, 2008), reduce the risk of long-term sickness absence (Clausen, Christensen, \& Borg, 2010) and increase the possibilities of returning to work after long-term sickness absence (Clausen, Friis Andersen, Bang Christensen, \& Lund, 2011). In a Swedish population study the work environment variables that were most clearly differentiated with regard to long-term good health related to a cluster of quality aspects, including being satisfied with the quality of one's own work and having the resources to perform work tasks well (Aronsson \& Lindh, 2004; Aronsson \& Blom, 2010). In addition, studies of Finnish teachers and dentists show that various energising job resources not only mitigate the negative impacts of job demands and work-life changes on work engagement but also seem to boost work engagement, particularly when job demands are high (Hakanen, Bakker, \& Demerouti, 2005; Bakker, Hakanen, Demerouti, \& Xanthopoulou, 2007).

Thus, creating a working environment that draws upon the knowledge generated within the field of positive work and organisational psychology could contribute to the ability of Nordic welfare societies to meet the aforementioned labour market challenges, both now and in the future. In order to reap these rewards, however, it is important to study the antecedents and consequences of experiences of positive affect in a variety of work settings. 


\subsection{Positive psychology and healthy organisations}

The conceptual framework presented in the model appears to be closely related to the concept of organisational health as it focuses on psychosocial work environment factors, individual well-being and indicators of organisational performance. According to Kivimäki and Lindström (2006), a healthy organisation has a dual focus, as the well-being of employees and organisational performance are simultaneously at the centre of attention. Accordingly, organisational health is construed as "the capability of the organisation to function effectively in relation to various environmental factors and to respond to various environmental changes" (Kivimäki \& Lindström, 2006, p. 811).

The concept of organisational health thus constitutes a nexus that allows the concepts of work environment, health and productivity to flow together to reach an optimal point at which well-being at the individual level is coexistent with efficient and productive work organisations. In terms of positive psychology the concept of organisational health thus appears to have interesting potential.

Drawing on Schaufeli and Bakker's Job Demands-Resources model (JD-R) (Schaufeli \& Bakker, 2004), we see that the individually experienced balance between job demands and job resources in the psychosocial work environment has an impact on the well-being of the individual. Schaufeli and Bakker describe job demands as "the things that have to be done and job resources as the aspects of the job that either/or (1) reduce job demands and the associated physiological and psychological costs; (2) are functional in achieving work goals; (3) stimulate personal growth, learning and development" (Schaufeli \& Bakker, 2004, p. 296). It furthermore follows from the JD-R model that the presence of resources in a work organisation predicts employee health and well-being whereas excessive demands predict burnout and ill-health.

Furthermore, Harter, Schmidt, and Hayes (2002) show that employee engagement are positively correlated with a series of organisational outcomes such as customer satisfaction, profits, turnover, and productivity. Taken together, the findings of Harter et al. (2002) and Schaufeli and Bakker (2004) lend credibility to the notion of a dynamics inherent in organisational health as they establish a link between factors in the psychosocial work environment and positive organisational outcomes via work-related well-being at the individual level. In measuring organisational health we thus need to focus on the following three aspects of the concept: psychosocial work environment, individual well-being and organisational performance. 


\subsection{Aims of the project and the report}

The aim of the project was to develop methods for measuring organisational health. The three dimensions of the concept of organisational health - psychosocial work conditions, employee well-being and organisational performance - were measured with a questionnaire that was developed by the research group.

\subsection{Conceptual framework}

The project group developed a questionnaire - the Nordic Questionnaire on Positive Organisational Psychology (N-POP) - that provides a full measure of organisational health by focusing on six dimensions of organisational life:

- individual resources

- job resources

- job demands

- work-related states and attitudes

- individual well-being

- organisational performance

This report is the product of research undertaken by a project group on positive work and organisational psychology that has been supported by the Nordic Council of Ministers since 2006. The project group has published two reports on Nordic research on positive work and organisational psychology in Sweden, Norway, Finland and Denmark (Christensen, 2008, 2009). In the first two reports, the project group devised and investigated a model of the relationship between job resources and individual resources on the one hand and work-related experiences and attitudes and organisational and individual outcomes on the other (Christensen, 2008, 2009). For the present report we have adapted the model from the first two reports, so that it reflects the concepts that we measure in the Nordic Questionnaire on Positive Organisational Psychology. Figure 1 presents the concepts that are measured in the N-POP; for a more complete description of these concepts, please refer to Appendix A. 
Figure 1. Conceptual framework of the Nordic Questionnaire on Positive Organisational Psychology

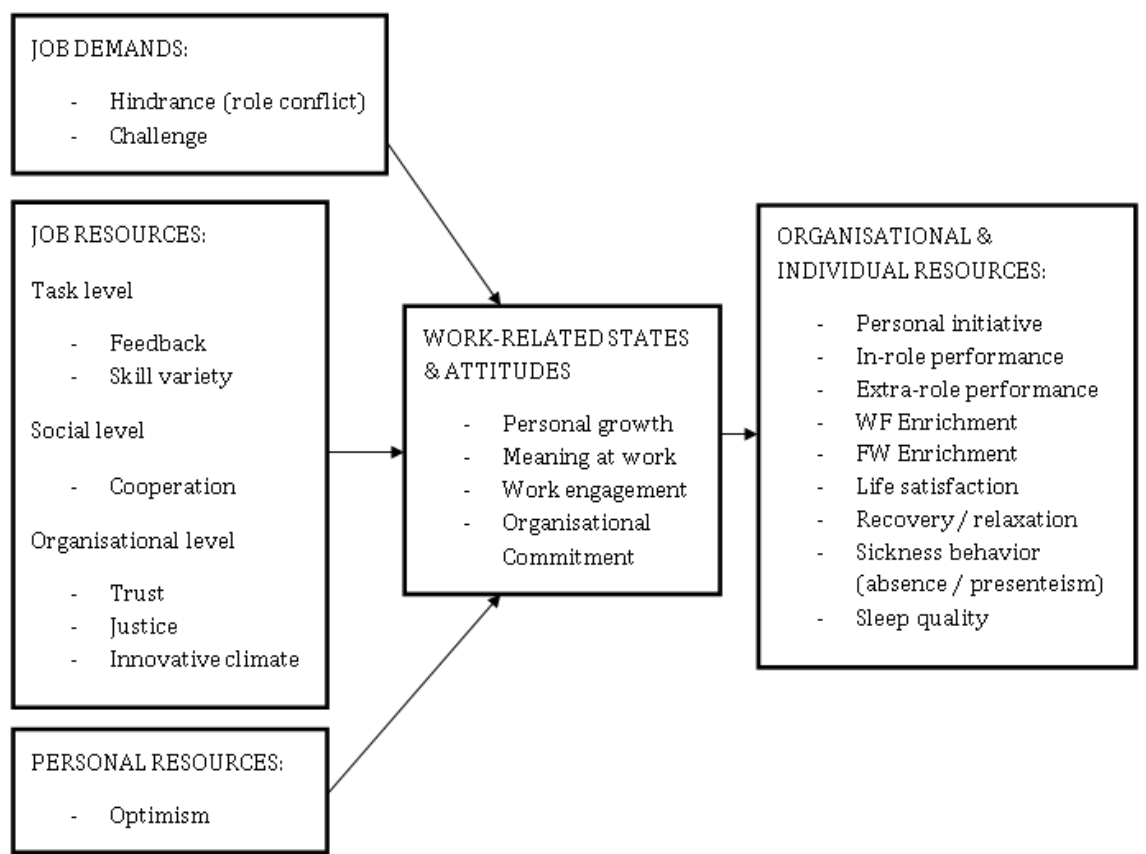

In this report, we present results for the reliability and construct validity of the scales that we included in the questionnaire. The analyses are based on responses from two study populations. The first study population consists of 180 Swedish white-collar workers and the other consists of a mixed sample of 202 Norwegian employees.

It is the hope of the researchers in the Nordic project group on positive work and organisational psychology that the findings in the present report will move the insights generated in the literature to the forefront of the Nordic agenda on how to create and sustain organisational health. It is furthermore hoped that the questionnaire developed during the present project will inspire work organisations to assess their organisational health - i.e. the mutually reinforcing presence of high organisational performance and high individual well-being. 



\section{Method}

\subsection{Sweden: Participants and procedure}

The Swedish participants were employed in a medium-sized bank and worked within financial services and within departments such as private marketing, development and administration. The bank is tied to a larger business group within the trade area and has about 300 employees, including the headquarters, which were not included in the study. A web survey was sent to 147 people. After three reminders the questionnaire was answered by 119 people, a response rate of 81 per cent. Some departments did not allow the web survey for safety reasons so instead a paper questionnaire was used. We sent out 100 paper questionnaires and received 61answers after three reminders. The overall response rate was thus 73 per cent. The Swedish survey consisted of 118 items that were essentially sub-questions of different scales and background questions (see Appendix B). The respondents were anonymous. For an overview of the Swedish questionnaire, see Appendix C.

\subsection{Norway: Participants and procedure}

The questionnaire was distributed to eight different workplaces. These eight workplaces were categorised into three different categories: accounting/revision $(n=44)$, hospitals $(n=69)$, and university college $(n=$ 89). The total sample consisted of 202 respondents. The first category "accounting/revision" included five different accounting units located in the middle of Norway. The second category "hospitals" included two hospitals situated in Trondheim and Tromsø. The third category "university college" included employees at a university college located in Trondheim. The eight included workplaces were quite similar to each other with some exceptions. The web survey was sent to 62 employees in accounting/revision, and was answered by 44 respondents, which gave a response rate of 71 per cent. Further, 158 employees in two hospitals received questionnaires; some 69 answered, which provided a response rate of 44 per cent. Finally, there were 89 respondents out of 713 in the university college, a response rate of 12 per cent. The data were treated with confidentiality and the respondents were anonymous. The Norwegian Social Science Data Services were asked for approval. The Norwegian survey consisted of 119 items that were mainly subquestions related to different dimensions, in addition to background 
questions (see Appendix B). For an overview of the Norwegian questionnaire, see Appendix D.

\subsection{Description of respondents in Sweden and Norway}

As can be seen in Table 1 the Swedish and Norwegian respondents were rather similar with regard to background variables with a few exceptions. In general the respondents were highly educated with a somewhat lower proportion of highly educated employees in the Norwegian accounting firm. Another exception is that the hospitals in this sample are predominantly staffed by women.

Table 1. Description of the participants in Norway and Sweden

\begin{tabular}{|c|c|c|c|c|c|}
\hline \multirow[b]{2}{*}{ Variable } & \multicolumn{2}{|c|}{ Sweden } & \multicolumn{3}{|c|}{ Norway } \\
\hline & Bank & $\begin{array}{r}\text { Accoun- } \\
\text { ting }\end{array}$ & Hospitals & University & $\begin{array}{r}\text { Total } \\
\text { Norway }\end{array}$ \\
\hline Number of respondents & 180 & 44 & 69 & 89 & 202 \\
\hline Age (m) & 40 & 45 & 43 & 48 & 46 \\
\hline Women (\%) & 64 & 52 & 94 & 63 & 71 \\
\hline Married or cohabiting (\%) & 77 & 82 & 68 & 76 & 75 \\
\hline Living with children at home (\%) & 54 & 61 & 66 & 57 & 39 \\
\hline University education (\%) & 45 & 23 & 61 & 78 & 60 \\
\hline$>7$ year at the workplace & 50 & 68 & 41 & 41 & 47 \\
\hline Permanent employment (\%) & 96 & 100 & 88 & 92 & 93 \\
\hline
\end{tabular}




\section{Results}

In the present chapter, we assess the reliability and construct validity of the scales included in the Nordic questionnaire on Positive Organisational Psychology. The internal consistency of the scales (reliability) is assessed using Cronbach's alpha coefficient and the construct validity of the scales are assessed using Pearson's $r$ correlations in order to investigate whether our measures are meaningfully associated with related constructs.

\subsection{Internal consistency of the scales}

Cronbach's alpha coefficient ( $\alpha$ ) (Cronbach, 1951) was used to evaluate the internal consistency (reliability) of the scales in this report. The Cronbach's alpha coefficient is an estimate of the correlation between all the included items and all of the included items and the construct (Cronbach, 1951), and the coefficient varies in value between zero and one. In his original article published in 1951, Cronbach assumes that if a scale has high internal consistency it is psychologically interpretable. The coefficient is dependent on the number of items, and generally it is easier to obtain a satisfactory alpha when many items are included. It should be noted that a high alpha value is ideal, although a scale does not necessarily need a high Cronbach's alpha to be useful.

In this report, we tested the alphas of both the Norwegian and the Swedish sample, also providing the total value. There are small differences in the values between the countries, and we chose also to report the total score as it is based on a larger number of respondents and is representative for the Nordic context. The internal consistencies of the scales varied between 0.66 and 0.87 as measured by Cronbach's alpha (see Table 2). To view the items, see Appendix B. Skill variety contained only two items, showing satisfactory intercorrelations in the two samples. Challenge demands consisted of aspects of quantitative, learning, and decision-making demands. It showed the lowest alpha value, i.e. 0.66 for the total sample. All scales representing positive factors, however, showed satisfactory alphas ranging from 0.70 (competence in personal growth) to 0.87 for meaning at work, in-role performance, and life satisfaction. 
Table 2. The scales and their internal consistencies (Cronbach's alphas) and single items in the questionnaire

\begin{tabular}{|c|c|c|c|c|c|}
\hline $\begin{array}{l}\text { Content area and } \\
\text { scale }\end{array}$ & $\begin{array}{l}\text { Scale } \\
\text { (see appendix B for items) }\end{array}$ & $\begin{array}{r}\text { Number of } \\
\text { items }\end{array}$ & $\begin{array}{r}\text { Alpha } \\
\text { (Norwegian } \\
\text { sample) }\end{array}$ & $\begin{array}{r}\text { Alpha } \\
\text { (Swedish } \\
\text { sample) }\end{array}$ & $\begin{array}{l}\text { Alpha } \\
\text { (Total) }\end{array}$ \\
\hline Individual resources & Optimism & 3 & .79 & .85 & .82 \\
\hline \multirow[t]{2}{*}{ Job demands } & Role conflicts & 3 & .72 & .70 & .71 \\
\hline & Challenge Demands & 7 & .68 & .68 & .66 \\
\hline \multirow[t]{6}{*}{ Job resources } & Skill variety* & 2 & .67 & .62 & .63 \\
\hline & Positive feedback & 6 & .70 & .80 & .75 \\
\hline & Trust & 4 & .77 & .67 & .74 \\
\hline & Justice & 4 & .86 & .82 & .84 \\
\hline & Co-operation & 6 & .85 & .81 & .84 \\
\hline & Innovative climate & 3 & .66 & .72 & .71 \\
\hline \multirow{9}{*}{$\begin{array}{l}\text { Work-related states } \\
\text { and attitudes }\end{array}$} & Personal & & & & \\
\hline & Growth: & 17 & .87 & - & .87 \\
\hline & Curiosity & 4 & .69 & .84 & .78 \\
\hline & Absorption & 3 & .80 & .81 & .80 \\
\hline & Complexity & 5 & .68 & .74 & .70 \\
\hline & Competence** & 5 & .81 & - & - \\
\hline & Engagement & 3 & .84 & .73 & .77 \\
\hline & Meaning at work & 7 & .90 & .83 & .87 \\
\hline & Organisational commitment & 4 & .72 & .74 & .76 \\
\hline \multirow{10}{*}{$\begin{array}{l}\text { Individual and organi- } \\
\text { sational outcomes }\end{array}$} & Personal initiative & 4 & .78 & .72 & .76 \\
\hline & In-role performance & 3 & .86 & .86 & .87 \\
\hline & Extra-role performance & 4 & .75 & .75 & .74 \\
\hline & Work-family enrichment & 3 & .87 & .82 & .85 \\
\hline & Family-work enrichment & 3 & .78 & .72 & .75 \\
\hline & Life satisfaction & 5 & .86 & .76 & .87 \\
\hline & Recovery and relaxation & 4 single items & & & \\
\hline & Sickness absence & 2 items & & & \\
\hline & Sickness presenteeism & 1 item & & & \\
\hline & Sleep quality & 3 single items & & & \\
\hline
\end{tabular}

* The intercorrelations between the two items measuring skill variety are 0.51 for Norwegian study populations, 0.46 for Swedish study populations and 0.46 for the entire study population.

** Competence dimension of personal growth was not included in the Swedish sample.

\subsection{Intercorrelations between the measures}

The bivariate intercorrelations of the scales are described in Tables 2 to 4. We grouped the variables into analyses that follow the structure of our working model (relationship between job and individual resources and job demands on the one hand, and work-related states and attitudes and organisational and individual outcomes on the other); see Figure 1. As regards the associations between job and personal resources and job demands, and the positive states and attitudes, we first noticed that optimism showed the highest correlation with personal growth (see Table 3 ). Interestingly, role conflicts were also positively correlated with personal growth, albeit negatively correlated with all other work-related experiences and attitudes. Personal growth was also more positively correlated with task-level resources and challenge demands than with social and organisational resources. Engagement, meaning at work, and organisational commitment all showed similar relationships with job 
and personal resources and job demands. They correlated positively with optimism, job resources, and challenge demands, and negatively with role conflicts (hindrance stressor). It could be seen that engagement and meaning at work correlated somewhat higher with task-level resources (skill variety and positive feedback), whereas organisational commitment had higher positive correlations with organisational resources such as trust and justice.

Table 3. Correlations ${ }^{1}$ between personal resources, job demands and job resources (row) and work-related states and attitudes (column)

\begin{tabular}{lllccc}
\hline Content area & Scale & $\begin{array}{c}\text { Personal } \\
\text { growth }\end{array}$ & Engagement & $\begin{array}{c}\text { Meaning } \\
\text { at work }\end{array}$ & $\begin{array}{c}\text { Organisational } \\
\text { commitment }\end{array}$ \\
\hline Personal resources & Optimism & $.37^{* * *}$ & $.28^{* * *}$ & $.30^{* * *}$ & $.29^{* * *}$ \\
Job demands & Role conflicts & $.13^{*}$ & $-.18^{* *}$ & $-.20^{* * *}$ & $-.22^{* * *}$ \\
& Challenge demands & $.21^{* * *}$ & $.35^{* * *}$ & $.36^{* * *}$ & $.23^{* * *}$ \\
Job resources & Skill variety & $.26^{* * *}$ & $.50^{* * *}$ & $.59^{* * *}$ & $.31^{* * *}$ \\
& Positive feedback & $.28^{* * *}$ & $.45^{* * *}$ & $.59^{* * *}$ & $.49^{* * *}$ \\
& Trust & .08 & $.27^{* * *}$ & $.31^{* * *}$ & $.45^{* * *}$ \\
& Justice & .08 & $.37^{* * *}$ & $.39^{* * *}$ & $.54^{* * *}$ \\
& Cooperation & .10 & $.37^{* * *}$ & $.48^{* * *}$ & $.53^{* * *}$ \\
& Innovative climate & $.13^{*}$ & $.34^{* * *}$ & $.42^{* * *}$ & $.49^{* * *}$ \\
\hline
\end{tabular}

$* * *$ Correlation is significant at the 0.001 level

***orrelation is significant at the 0.01 level.

*correlation is significant at the 0.05 level (two-tailed).

Table 4 shows the associations between job and individual resources and job demands, and several outcomes. For personal resources, optimism was positively related to all forms of good job performance: personal initiative, in-role performance, and extra-role performance. Similarly, job resources were generally positively, albeit more weakly than optimism, related to self-reported performance measures. Role conflicts were negatively associated and challenge demands not associated with in-role performance. Challenge demands were, however, positively related to personal initiative and extra-role performance.

Optimism also seems to be an important personal resource for recovery \&relaxation, sleep quality, and life satisfaction. Moreover, optimistic employees seemed to be less absent from work, and they were less sickness present. Job resources did not correlate with sickness absenteeism and presenteeism, except for trust and justice that correlated negatively with sickness presenteeism. In addition and similarly to optimism, job resources associated positively with recovery and sleep variables and with life satisfaction.

As regards job demands, challenge demands were unrelated to sickness absenteeism and presenteeism and to recovery and sleep quality. Interestingly, challenge demands were positively related to life satisfaction. In contrast, role conflicts were negatively associated with life satisfaction, recovery and sleep quality, and positively with presenteeism, indicating that challenge and hindrance (role conflicts) demands relate differently to employee well-being. 
Finally, job resources and optimism were positively associated with both work-to-family and family-to-work enrichment. Similar positive associations could be found with work-family variables and challenge stressors. Role conflicts were not related to enrichment experiences between work and family.

\begin{tabular}{|c|c|c|c|c|c|c|c|c|c|c|c|}
\hline $\begin{array}{l}\text { Content } \\
\text { area }\end{array}$ & Scale & $\begin{array}{l}\text { Personal } \\
\text { initiative }\end{array}$ & $\begin{array}{l}\text { In-role } \\
\text { perfor- } \\
\text { mance }\end{array}$ & $\begin{array}{c}\text { Extra-role } \\
\text { performance }\end{array}$ & $\begin{array}{l}\text { Sickness } \\
\text { absence }\end{array}$ & $\begin{array}{l}\text { Sickness } \\
\text { presence }\end{array}$ & $\begin{array}{c}\text { WF } \\
\text { enrich- } \\
\text { ment }\end{array}$ & $\begin{array}{c}\text { FW } \\
\text { enrichment }\end{array}$ & $\begin{array}{c}\text { Recovery } \\
\text { and } \\
\text { relaxation } 2\end{array}$ & $\begin{array}{c}\text { Sleep } \\
\text { quality } 3\end{array}$ & $\begin{array}{l}\text { Life satis- } \\
\text { faction }\end{array}$ \\
\hline $\begin{array}{l}\text { Personal re- } \\
\text { sources }\end{array}$ & Optimism & $.37^{* * *}$ & $.32 * * *$ & $.30 * * *$ & $-.17^{* *}$ & $-.17^{* *}$ & $.13^{*}$ & $.27^{* *}$ & $.32 * * *$ & $.24 * * *$ & $.42^{* * *}$ \\
\hline \multirow[t]{2}{*}{ Job demands } & Role conflicts & .11 & $-.20 * * *$ & .06 & -.01 & $-.14 *$ & .00 & -.02 & $-.23 * * *$ & $-.16^{* *}$ & $-.17^{* *}$ \\
\hline & $\begin{array}{l}\text { Challenge } \\
\text { demands }\end{array}$ & $.28^{* * *}$ & .06 & $.24 * * *$ & -.01 & .06 & $.21 * * *$ & $.19 * * *$ & .04 & .01 & $.16^{* *}$ \\
\hline \multirow[t]{6}{*}{ Job resources } & Skill variety & $.23 * * *$ & $.28^{* * *}$ & $.24 * * *$ & .02 & .01 & $.32 * * *$ & $.11^{*}$ & $.22 * *$ & $.11^{* *}$ & $.26^{* *}$ \\
\hline & $\begin{array}{l}\text { Positive } \\
\text { feedback }\end{array}$ & $.32 * * *$ & $.27^{* * *}$ & $.30 * * *$ & -.06 & -.06 & $.31 * * *$ & $.19 * * *$ & $.21 * * *$ & $.14^{*}$ & $.29 * * *$ \\
\hline & Trust & $.14^{*}$ & .08 & $.11^{*}$ & -.06 & $-.20 * * *$ & $.11^{*}$ & .07 & $.21 * * *$ & $.14^{* *}$ & $.16^{* *}$ \\
\hline & Justice & $.15^{* *}$ & .09 & $.12^{*}$ & -.06 & $-.25 * * *$ & $.18^{* *}$ & $.12 *$ & $.21 * * *$ & $.12^{*}$ & $.24 * * *$ \\
\hline & Cooperation & $.23 * * *$ & $.25 * * *$ & $.22 * * *$ & -.03 & -.08 & $.22 * * *$ & $.23 * * *$ & $.21 * * *$ & .09 & $.30 * * *$ \\
\hline & $\begin{array}{l}\text { Innovative } \\
\text { climate }\end{array}$ & $.18^{* *}$ & $.16^{* *}$ & $.18^{* *}$ & -.04 & -.05 & $.28^{* * *}$ & $.26 * * *$ & $.16^{* *}$ & .07 & $.29 * * *$ \\
\hline
\end{tabular}

Note $1 .{ }^{* *}$ Correlation is significant at the 0.001 level $* *$; correlation is significant at the 0.01 level; *correlation is significant at the 0.05 level.

Note 2 . The recovery and relaxation item used in this Table was "I feel rested and recovered when I return to work after a weekend.

Note 3. Sleep quality used in this Table was "Upon waking during the past week, how often have you felt that you have had sufficient sleep.

In Table 5 we present the associations between work-related states and attitudes, and the outcomes included in our questionnaire. Table 4 shows that all the positive states and attitudes were positively related to the self-reported performance measures, i.e. personal initiative and inrole and extra-role behaviour. Personal growth, however, had the highest positive correlations with different types of job performance.

As regards the positive states and attitudes and sickness absenteeism and presenteeism the associations were negative but did not reach statistical significance except between organisational commitment and presenteeism.

In addition, personal growth, engagement, meaning at work, and organisational commitment were all positively correlated with both workto-family enrichment and family-to-work enrichment. Of the positive state measures meaning at work showed the highest associations with work and family enriching each other. 
Moreover, engagement, meaning at work, and organisational commitment were positively associated with recovery and relaxation and with sleep quality. Personal growth, however, was unrelated to these variables. Finally, all the positive states and attitudes positively correlated with life satisfaction, engagement and meaning at work scoring somewhat higher than personal growth and organisational commitment.

Table 5. Correlations ${ }^{1}$ between work-related states and attitudes (row) and individual and organisational outcomes

\begin{tabular}{|c|c|c|c|c|c|c|c|c|c|c|c|}
\hline Content area & Scale & 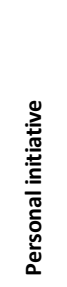 & 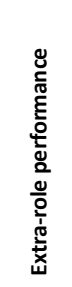 & 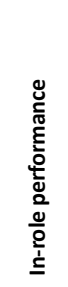 & 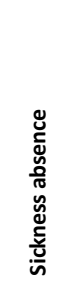 & 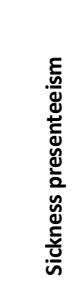 & 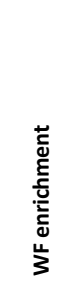 & 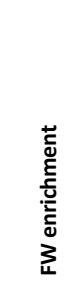 & 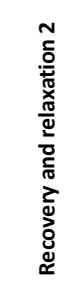 & 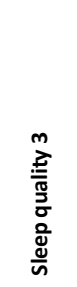 & 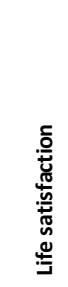 \\
\hline \multirow{4}{*}{$\begin{array}{l}\text { Work-related } \\
\text { states and } \\
\text { attitudes }\end{array}$} & $\begin{array}{l}\text { Personal } \\
\text { growth }\end{array}$ & $.64^{* *}$ & $.43^{* *}$ & $.29 * *$ & -.03 & $.12 *$ & $.27^{* *}$ & $.26 * *$ & .07 & .02 & $.20 * *$ \\
\hline & $\begin{array}{l}\text { Engage- } \\
\text { ment }\end{array}$ & $.26 * *$ & $.21 * *$ & $.20^{* *}$ & -.08 & -.04 & $.31^{* *}$ & $.19 * *$ & $.32 * *$ & $.24^{* *}$ & $.40^{* *}$ \\
\hline & $\begin{array}{l}\text { Meaning } \\
\text { at work }\end{array}$ & $.30 * *$ & $.31 * *$ & $.32 * *$ & -.05 & -.10 & $.48^{* *}$ & $.31 * *$ & $.33^{* *}$ & $.20 * *$ & $.41^{* *}$ \\
\hline & $\begin{array}{l}\text { Organi- } \\
\text { sational } \\
\text { commit- } \\
\text { ment }\end{array}$ & $.27^{* *}$ & $.19 * *$ & $.22^{* *}$ & -.04 & $-.12^{*}$ & $.31^{* *}$ & $.29 * *$ & $.26 * *$ & $.17^{* *}$ & $.31^{* *}$ \\
\hline
\end{tabular}

Note1. $* * *$ Correlation is significant at the 0.001 level; ** correlation is significant at the 0.01 level; *correlation is significant at the 0.05 level.

Note 2 . Recovery and relaxation item used in this Table was "I feel rested and recovered when I return to work after a weekend".

Note 3. Sleep quality used in this Table was "Upon waking during the past week, how often have you felt that you have had sufficient sleep?"

Table 6 shows the intercorrelations between personal resources, job demands and job resources. It shows that all the correlations came out as positive except those with role conflicts. The highest correlations emerged between cooperation and justice, cooperation and innovative climate, and trust and justice. The results showed further that challenge demands did have a significant correlation with trust or justice. 
Table 6. Intercorrelations between personal resources, job demands and job resources

\begin{tabular}{|c|c|c|c|c|c|c|c|c|c|c|}
\hline $\begin{array}{l}\text { Content } \\
\text { area }\end{array}$ & Scale & Optimism & $\begin{array}{l}\text { Role } \\
\text { conflicts }\end{array}$ & $\begin{array}{l}\text { Challenge } \\
\text { demands }\end{array}$ & $\begin{array}{c}\text { Skill } \\
\text { variety }\end{array}$ & $\begin{array}{l}\text { Positive } \\
\text { feedback }\end{array}$ & Trust & Justice & $\begin{array}{c}\text { Coopera- } \\
\text { tion }\end{array}$ & $\begin{array}{l}\text { Innovative } \\
\text { climate }\end{array}$ \\
\hline $\begin{array}{l}\text { Personal } \\
\text { resources }\end{array}$ & Optimism & & $-.16 * *$ & $.13^{*}$ & $.16^{* *}$ & $.35 * * *$ & $.13^{* *}$ & $.23 * * *$ & $.29 * * *$ & $.22^{* * *}$ \\
\hline \multirow[t]{2}{*}{ Job demands } & Role conflicts & & & $.24^{* * *}$ & $-.15 * *$ & $-.24 * * *$ & $-.37 * * *$ & $-.41 * * *$ & $-.41 * * *$ & $-.30 * * *$ \\
\hline & $\begin{array}{l}\text { Challenge } \\
\text { demands }\end{array}$ & & & & $.33^{* * *}$ & $.34 * * *$ & .03 & .10 & $.23^{* * *}$ & $.20^{* * *}$ \\
\hline \multirow[t]{5}{*}{ Job resources } & Skill variety & & & & & $.47^{* * *}$ & $.14^{* *}$ & $.23 * * *$ & -35 & $.23 * * *$ \\
\hline & $\begin{array}{l}\text { Positive } \\
\text { feedback }\end{array}$ & & & & & & $.38^{* * *}$ & $.52 * * *$ & .57 & $.50 * * *$ \\
\hline & Trust & & & & & & & $.66^{* * *}$ & .44 & $.50 * * *$ \\
\hline & Justice & & & & & & & & .64 & $.56^{* * *}$ \\
\hline & Cooperation & & & & & & & & & $.64 * * *$ \\
\hline
\end{tabular}

Note. ${ }^{* * *}$ Correlation is significant at the 0.001 level; ${ }^{* *}$ correlation is significant at the 0.01 level; *correlation is significant at the 0.05 level.

Table 7 presents intercorrelations between work-related experiences and attitudes. The results showed that all intercorrelations were positively and significantly associated with each other. The highest correlations emerged among meaning and work and organisational commitment, and meaning at work and engagement. The lowest correlation was found between personal growth and organisational commitment.

Table 7. Intercorrelations between work-related experiences and attitudes

\begin{tabular}{llcrrr}
\hline Content area & Scale & $\begin{array}{r}\text { Personal } \\
\text { growth }\end{array}$ & $\begin{array}{r}\text { Enga- } \\
\text { gement }\end{array}$ & $\begin{array}{r}\text { Meaning } \\
\text { at work }\end{array}$ & $\begin{array}{r}\text { Org. com- } \\
\text { mitment }\end{array}$ \\
\hline \multirow{2}{*}{ Work-related experiences and attitudes } & Personal growth & & $.21^{* * *}$ & $.31^{* * *}$ & $.19^{* * *}$ \\
& $\begin{array}{l}\text { Engagement } \\
\text { Meaning at }\end{array}$ & & $.56^{* * *}$ & $.39^{* * *}$ \\
& work & & & $.58^{* * *}$ \\
& & & & \\
\hline
\end{tabular}

Note. ${ }^{* * *}$ Correlation is significant at the 0.001 level; ** correlation is significant at the 0.01 level; *correlation is significant at the 0.05 level.

In Table 8 the intercorrelations between work-related outcomes were presented. The results showed that the highest correlations appeared between recovery-relaxation and sleep quality, family-work enrichment and life satisfaction, and personal initiative and extra role performance. Many of the intercorrelations between the outcome variables did not emerge as significant. 
Table 8. Intercorrelations between work-related outcomes

\begin{tabular}{|c|c|c|c|c|c|c|c|c|c|c|}
\hline Scale & 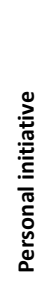 &  & 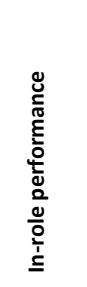 & 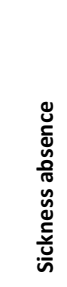 & 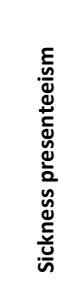 & 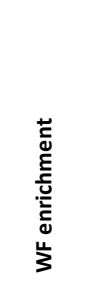 & 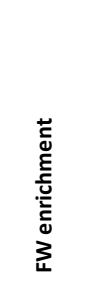 & 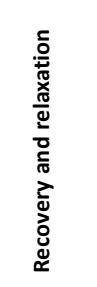 & $\begin{array}{l}\frac{\vec{z}}{\bar{T}} \\
\frac{0}{\sigma} \\
\frac{0}{d} \\
\frac{d}{n}\end{array}$ & 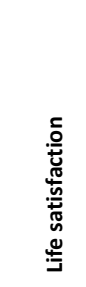 \\
\hline Personal initiative & & $.44 * * *$ & $.32 * * *$ & -.01 & .09 & .10 & $.24 * * *$ & .09 & -.01 & $.24 * * *$ \\
\hline $\begin{array}{l}\text { Extra-role } \\
\text { performance }\end{array}$ & & & $.43^{* * *}$ & .00 & -.00 & $.21 * * * *$ & $.16^{* *}$ & $.14^{* *}$ & .10 & $.21 * * *$ \\
\hline $\begin{array}{l}\text { In-role } \\
\text { performance }\end{array}$ & & & & -.05 & -.02 & $.17^{* *}$ & $.16^{* *}$ & $.19 * *$ & $.18^{* *}$ & $.28^{* * *}$ \\
\hline Sickness absence & & & & & .10 & .03 & .07 & -.13 & $-.23 * * *$ & $-.20 * * *$ \\
\hline $\begin{array}{l}\text { Sickness } \\
\text { presenteeism }\end{array}$ & & & & & & .04 & .01 & $-.13^{*}$ & $-.12^{*}$ & $-.15^{*}$ \\
\hline WF enrichment & & & & & & & $.40^{* * * *}$ & $.21^{* * *}$ & .08 & $.22 * * *$ \\
\hline FW enrichment & & & & & & & & $.17^{* *}$ & .05 & $.45^{* * *}$ \\
\hline $\begin{array}{l}\text { Recovery and } \\
\text { relaxation }\end{array}$ & & & & & & & & & $.59 * * *$ & $.41^{* * *}$ \\
\hline Sleep quality & & & & & & & & & & $.29 * * *$ \\
\hline
\end{tabular}

Note. ${ }^{* * *}$ Correlation is significant at the 0.001 level; $* *$ correlation is significant at the 0.01 level; *correlation is significant at the 0.05 level. 



\section{Discussion}

The aim of this report was to investigate the relevance of a series of positive psychological concepts in a Nordic context. As stated in the introduction, Nordic welfare societies are faced with a dual challenge in terms of ageing populations on the one hand and increasing competitive pressures from a globalised economy on the other. It is the contention of the authors of the present report that the insight of positive work and organisational psychology could contribute to enhancing the long-term sustainability of the Nordic economies as on the one hand it helps to increase the labour supply in the Nordic countries and on the other hand an increased focus on a positive psychosocial work environment could help to bolster the productive capacities of employees and organisations without compromising the long-term health of either.

In this report we test the working model that we put forward and tested in previous reports (Christensen, 2008, 2009). As stated in the introduction, using the first two reports we have adapted the model to reflect the concepts that we measure in the Nordic Questionnaire on Positive Organisational Psychology (N-POP). See Figure 1.

The working model posits that job and individual resources and job demands have an impact on a series of work-related states and attitudes that again are of importance for a variety of individual and organisational outcomes such as employee retention, sickness absence, well-being and productivity. In this respect the working model links factors in the psychosocial work environment with a series of positive psychological states and outcomes that are of simultaneous importance at the individual, the organisational and the societal level (see Figure 1).

The working model is inspired by the Job Demands-Resources (JD-R) model (Schaufeli and Bakker, 2004) and the Conservation of Resources (COR) theory (Hobfoll, 2001). According to the JD-R model, job resources are primarily associated with positive work-related states (e.g. high levels of work engagement), which again have an impact on employee commitment and performance, whereas job demands are primarily associated with more negative work-related states (e.g. high levels of burnout), which again are expected to have an adverse impact on the health of the individual. In addition, the COR theory posits that resources are central in determining the adaptive capacities of the individual. The availability of work-related resources (in terms of job resources and positive work-related states and attitudes) can therefore be considered of great importance for the abilities of individual employees to deal with 
the stresses and strain of their daily working life while still maintaining their health and well-being in the long term.

In the working model we therefore accord theoretical primacy to job and individual resources and job demands. Accordingly, these entities are expected to have an impact on the work-related states and attitudes that are placed at the centre of the working model, and these work-related states and attitudes are then expected to be important in the framing of a variety of organisational and individual outcomes. The positioning of the concepts is largely done for analytical purposes, however, and it is reasonable to assume that some reversed and reciprocal causality may also be at play (e.g. Hakanen, Perhoniemi, \& Toppinen-Tanner, 2008; Hakanen, Peeters, \& Perhoniemi, 2011). For instance, the outcomes at the individual or organisational level could be expected to have an impact on both workrelated states and attitudes of individual employees and on the psychosocial work environment in the work organisation. For analytical purposes, however, we stuck to the working model when analysing associations between job demands, job resources, work-related states and various outcomes, but in the real world it is important to be aware that the empirical phenomena that we investigate are intertwined.

\subsection{Discussion of results}

In this report we have evaluated the psychometric properties of the scales we included in the Nordic questionnaire on Positive Organisational Psychology - N-POP - that was administered to a Norwegian $(\mathrm{N}=202)$ and a Swedish $(\mathrm{N}=180)$ sample of employees. We decided to assess the internal consistencies of the included scales as well as the construct validity of the scales.

We assessed the internal consistency of the scales by calculating Cronbach's alpha coefficients for all scales including three items or more. By and large all 17 scales that included three or more items exhibited satisfactory Cronbach's alpha values. When we compared the two samples the results showed that there were some differences in the internal consistencies of the scales between the two samples. These differences were relatively small, however, which leads us to conclude that the scales must be considered to be relatively robust measures of the empirical phenomena that they are supposed to measure, as the internal consistency measures are similar in the Swedish and the Norwegian study populations.

In assessing the construct validity of the measures included in the $\mathrm{N}$ POP, we conducted a correlation analysis of the included measures. We conducted tests of the construct validity of the included measures in three steps.

In the first step we correlated scales measuring job resources, personal resources and job demands with scales measuring work-related 
states and attitudes. These analyses showed that job resources by and large correlated positively and significantly with the four scales measuring work-related states and attitudes. The results therefore affirm the construct validity of the measures of job resources and work-related states and attitudes as these measures are statistically associated while still being empirically distinguishable. This conclusion also holds true for the assessment of the construct validity of our one measure for personal resources (optimism) vis-à-vis the four measures of work-related states and attitudes, as these scales also exhibit moderate to strong correlations. Finally, in this first step of the analysis we examined the construct validity of the scales measuring job demands with reference to our four scales measuring work-related states and attitudes. This analysis showed that three of our four measures of work-related states and attitudes correlated negatively with experiences of role conflicts whereas one measure of work-related states and attitudes correlated positively with role conflicts. Surprisingly, our more general measures of job demands correlated positively with the four scales measuring workrelated states and attitudes. These findings leads us to conclude that some job demands such as role conflicts may be considered occupational hindrances that could prevent employees from doing their job properly, thereby clashing with professional identities, whereas other types of job demands may be considered challenges that, if dealt with successfully, could affirm the professional identities of employees (cf. Podsakoff, LePine, \& LePine, 2007).

In the second step of the analysis we investigated the construct validity of job resources, personal resources and job demands vis-à-vis the scales measuring organisational and individual outcomes. The correlation analysis showed that job resources by and large correlated positively with the scales measuring organisational and individual outcomes, which supports the construct validity of the included measures. No significant correlations were found between job resources and sickness absence, which is surprising as other studies have demonstrated robust associations between job resources and risk of sickness absence (e.g. Clausen, Nielsen, Caneiro, \& Borg, 2012). The correlation analyses furthermore showed that trust and justice were negatively associated with instances of sickness presenteeism, which indicates that employees who experience organisational trust and justice may be confident in the abilities of their colleagues to do the job properly, which reduces their propensity to go to work in spite of illness. The personal resource of optimism also showed moderate to strong positive correlations with most of the scales measuring organisational and individual outcomes and optimism was furthermore negatively correlated with both sickness absence and sickness presenteeism. The results regarding job demands and organisational and individual outcomes are in line with the findings observed above as role conflicts (hindrance demands) are associated with reduced in-role performance, recovery, family-work enrichment and 
sleep quality and increased risk of sickness absence, whereas the general job demands (challenge demands) are associated with increased personal initiative, extra-role performance, work-family enrichment and sleep quality.

In the third step of the analysis of the construct validity of the scales in the N-POP we correlated the scales measuring work-related states and attitudes with the scales measuring organisational and individual outcomes. The results of these analyses showed that all four measures of work-related states and attitudes were positive and significantly correlated with personal initiative, role-performance, work-family/familywork enrichment and life satisfaction. The scales measuring work engagement, meaning at work and organisational commitment were furthermore significantly positively associated with the sleep quality and recovery of the respondents. The results of the third step of the analysis of the construct validity of the scales in the N-POP therefore support the construct validity of the included scales as the analysis shows that the scales are statistically associated in accordance with our expectations while still being empirically distinguishable.

All in all the analyses of the reliability (internal consistency) and construct validity of the scales included in the Nordic questionnaire lead us to conclude that the N-POP constitutes a reliable and valid instrument for assessing the psychosocial work environment, work-related states and attitudes and a series of organisational and individual outcomes in modern work organisations. The fact that the N-POP was tested and yielded similar results in two countries furthermore lends credibility to the robustness of the measures in the questionnaire.

\subsection{When to use the N-POP}

The N-POP can be used as a survey instrument for investigating the working climate in modern work organisations. The N-POP has been constructed for assessing employees' perceptions of their work conditions, work-related states and various individual and organisational outcomes in order to:

- provide a basis for organisational development and interventions

- document changes in working conditions and evaluate organisational interventions

- aid research into associations between work, individual well-being, health, and productivity 


\subsection{How to use results from the N-POP}

The N-POP gives an impression of employees' perceptions of their work conditions, work-related states and various individual and organisational outcomes. It is important, however, to state that a survey of this nature does not yield the full truth of perceptions, feelings and sentiments in a modern work organisation but must rather be seen as a snapshot of organisational life that reflects the perceptions, feelings and sentiments of the employees who respond to the questionnaire. It may well be that a survey of this nature over- or underestimates the problems that exist in an organisation and it is therefore important to discuss the results of the survey thoroughly in the work organisation so that the findings are put into a proper perspective. It is also important to be aware of the possible need to deal with the problems uncovered in a survey. It may well be that it is difficult to deal with some issues that appear to constitute a problem for the employees. For instance, in working with people it may be difficult to escape emotional strain, or in the knowledge industry it may be difficult to escape experiences of cognitive strain. It is important to be aware of these issues and to support employees to cope as well as possible with the demands: for instance, by boosting job resources, developing competences or changing the organisation so that the work is more conveniently planned.

It is essential that the findings of the survey are discussed thoroughly at the workplace, as it is important to identify and deal with the actual causes of the observed problems rather than just treating the symptoms identified in the survey. In addition, it is up to the organisational members to determine if the identified issues really constitute a genuine problem in the organisation that must be dealt with or whether the identified issues are trivial for the organisational members. It is important to point out that the members of the organisations are the actual experts on their work environment and well-being and that decisions about which issues to deal with are therefore influenced by the members of the organisation.

Finally, it is worth noting that the true aim of positive work psychology does not include a primary focus on risks and problems. Using the NPOP gives an excellent opportunity to identify existing and potential resources and strengths that, once recognised, can be further enhanced in the organisation. Developing flourishing workplaces is not only about solving problems but also, more importantly, about building positive qualities, such as personal growth, engagement, and healthy practices in the organisation. 


\subsection{Strengths and limitations}

It must be considered a major strength of the Nordic questionnaire on Positive Organisational Psychology that it is part of a long-standing Nordic collaboration looking into positive factors at work. The research group that consists of researchers from Norway, Sweden, Finland and Denmark has collaborated since 2006 and the N-POP can therefore be considered a product of the accumulated experiences of the research group.

Second, it can be considered a strength of the N-POP that it is informed by two of the most dominant theories within the field of positive organisational psychology - namely the Job Demands-Resource model (Schaufeli \& Bakker, 2004) and the conservation of resources theory (Hobfoll, 2001). The questionnaire is therefore solidly anchored within the research traditions of positive organisational psychology, which emphasises that work must be considered a creative activity that, potentially, contributes to enhancing well-being and personal growth. Third, the measures that have been included in the N-POP have been validated and used in other research. Many of the applied measures, however, have been abbreviated in the N-POP, which enhances the feasibility of using these measures in the practical assessment of the work climate in modern work organisations.

It can, however, be considered a limitation of the validation of the $\mathrm{N}$ POP that the validation procedure is based on relatively small samples. It is furthermore important to stress that the data have been collected in only one Swedish company and four Norwegian companies and that the results therefore cannot be considered representative of the Swedish and Norwegian working populations. Finally, the results are based on cross-sectional data and it is therefore not possible to draw causal inferences from the results presented in the present report. Furthermore, the fact that all data are collected at one time-point also means that it cannot be ruled out that some of the observed correlations could be owed to common method biases (Podsakoff, MacKenzie, Lee, \& Podsakoff, 2003). 


\section{Conclusion}

In the present report we have presented results for the reliability and validity of a new Nordic questionnaire on Positive Organisational Psychology - N-POP. The analyses indicate that the N-POP has satisfactory reliability and construct validity. The questionnaire contributes a new perspective on organisational psychology as it is anchored within the research traditions of positive organisational psychology, which emphasises that work must be considered a creative activity that, potentially, contributes to enhancing well-being and personal growth. Finally, the results of the analyses lend credibility to the notion of organisational health as the concepts of work environment, health and productivity indeed do seem to flow together to an optimal point at which well-being at the individual level is coexistent with an efficient and productive work organisation. 



\section{References}

Aronsson, G., \& Blom, V. (2010). Work conditions for workers with good long-term health. International Journal of Workplace Health Management, 3, 160-172.

Aronsson, G., \& Lindh, T. (2004). Långtidsfriskas arbetsvilkor - En populationsstudie [Long-term health at work - a study of the population]. (Arbete och Hälsa: 10). Stockholm: Arbetslivsinstitutet.

Bolte, A., Goschkey, T., \& Kuhl, J. (2003). Emotion and intuition: Effects of positive and negative mood on implicit judgements of semantic coherence. Psychological Science, 14(5), 416-421.

Bakker, A., Hakanen, J., Demerouti, E., \& Xanthopoulou, D. (2007). Job resources boost work engagement, particularly when job demands are high. Journal of Educational Psychology, 99,(2) 274-284.

Christensen, M. (2008). Positive factors at work. The first report of the Nordic Project. Copenhagen: Nordic Council of Ministers.

Christensen, M. (2009). Validations and test of central concepts in positive work and organizational psychology. The second report from the Nordic Project "Positive factors at work." Copenhagen: Nordic Council of Ministers.

Clausen, T. (2009). Psychosocial work characteristics, positive work-related states, and labour market outcomes. A study on the antecedents and consequences of af fective organizational commitment and experience of meaning at work [Doctoral dissertation]. Copenhagen: The Danish Research School of Psychology.

Clausen, T. \& Borg, V. (2010). Do positive work-related states mediate the association between psychosocial work characteristics and turnover? A longitudinal analysis. International Journal of Stress Management, 17, 308-324.

Clausen, T., Christensen, K. B., \& Borg, V. (2010). Positive work-related states and long-term sickness absence: A study of register-based outcomes. Scandinavian Journal of Public Health, 38(Suppl 3), 51-58.

Clausen, T., Friis Andersen, M., Bang Christensen, K., \& Lund, T. (2011). Return to work among long-term sickness absent employees in eldercare - a prospective analysis of register-based outcomes. International Journal of Rehabilitation Research, 34(3), 249-254.

Clausen, T., Nielsen, K., Caneiro, I.G., \& Borg, V. (2012). Job demands, job resources and long-term sickness absence in the Danish eldercare services: a study of register based outcomes. Journal of Advanced Nursing 68, 127-136.

Cronbach, L.J. (1951). Coefficient alpha and the internal structure of tests. Psychometrica, 16(3), 297-334.

Esping Andersen, G. (2002). Why we need a new welfare state. Oxford: Oxford University Press.

Ferrie, J. E., Shipley, M. J., Marmot, M. G., Martikainen, P., Stansfeld, S. A., \& Smith, G. D. (2001). Job insecurity in white-collar workers: Toward an explanation of association with health. Journal of Occupational Health Psychology, 6(1), 26-42.

Fredrickson, B. L., \& Losada, M. F. (2005). Positive affect and the complex dynamics of human flourishing. American Psychologist, 60(7), 678-686.

Fredrickson, B. L., Tugade, M. M., Waugh, C. E., \& Larkin, G. R. (2003). What are good emotions in crisis? A prospective study of resilience and emotions following the terrorist attacks on the United States on September 11th, 2001. Journal of Personality and Social Psychology, 84(2), 365-376. 
Gable, S. L., \& Haidt, J. (2005). What (and why) is positive psychology? Review of General Psychology, 9, 103-110.

Glazer, S. \& Kruse, B. (2008). The role of organizational commitment in occupational stress models. International Journal of Stress Management, 15, 329-344.

Hakanen, J. J., Bakker, A. B., \& Demerouti, E., 2005. How dentists cope with their job demands and stay engaged: The moderating role of job resources. European Journal of Oral Sciences, 113, 479-487.

Hakanen, J. J., Peeters, M., \& Perhoniemi, R. (2011). Enrichment processes and gain spirals at work and at home: A three-year cross-lagged panel study. Journal of Occupational and Organizational Psychology: A Special Section for Extending the Boundaries of Psychological Resource Theories in Organizations, 84, 8-30.

Hakanen, J. J., Perhoniemi, R., \& Toppinen-Tanner, S. (2008). Positive gain spirals at work: From job resources to work engagement, personal initiative and work-unit innovativeness. Journal of Vocational Behavior, 73, 78-91.

Harter J.K., Schmidt, L.F., \& Hayes, T.L (2002) Business-unit-level relationship between employee satisfaction, employee engagement, and business outcomes: A meta-analysis. Journal of Applied Psychology, 87(2), 268-279.

Hobfoll, S. E. (2001), "The influence of culture, community, and the nested-self in the stress process: Advancing Conservation of Resources theory." Applied Psychology: An International Review, 50(3), 337-370.

Isen, A. M., Daubman, K. A., \& Nowicki, G. P. (1987). Positive affect facilitates creative problem solving. Journal of Personality and Social Psychology, 52(6), 1122-1131.

Kivimäki, M., \& Lindström, K. (2006). Psychosocial approach to occupational health. In G. Salvendy (Ed.), Handbook of human factors and ergonomics (pp. 801-817). New Jersey: John Wiley \& Sons.

Meyer, J.P., \& Allen, N. J. (1997). Commitment in the workplace. Theory, research and application. Thousand Oaks, CA: Sage.

Nordic Council of Ministers (2006). Nordic statistical yearbook 2006. Copenhagen: Nordic Council of Ministers.

Podsakoff, N. P., LePine, J. A., \& LePine, M. A. (2007), “Differential challenge stressorhindrance stressor relationships with job attitudes, turnover intentions, turnover, and withdrawal behavior: A meta-analysis." Journal of Applied Psychology, 92(2), 438-454.

Podsakoff, P. M., MacKenzie, S. B., Lee, J. Y., \& Podsakoff, N. P. (2003). “Common method biases in behavioral research: a critical review of the literature and recommended remedies." Journal of Applied Psychology, 88(5), 879-903.

Schaufeli, W. \& Bakker, A. (2004). Job demands, job resources, and their relationship with burnout and engagement: a multi-sample study. Journal of Organizational Behavior, 25, 293-315.

Seligman, M. E. P., \& Csikszentmihalyi, M. (2000). Positive psychology: An introduction. American Psychologist, 55, 5-14.

Turner, N., Barling, J., \& Zacharatos, A. (2002). Positive psychology at work. In C. R. Snyder \& S. J. Lopez (Eds.), Handbook of positive psychology (pp. 715-730). Oxford: Oxford University Press.

Wrzesniewski, A., \& Dutton, J. E. (2001). Crafting a job: Revisioning employees as active crafters of their work. Academy of Management Review, 26, 179-201. 


\section{Tiivistelmä}

Tämä raportti perustuu Pohjoismaiden Ministerineuvoston rahoittaman "Kohti työn imua ja terveitä organisaatioita" -hankkeessa ("Building engagement and healthy organisations") saatuihin tuloksiin. Projekti on pohjoismainen yhteishanke, johon osallistuivat Norja (Norjan tiede- ja teknologiayliopiston psykologian osasto), Tanska (Työelämän kansallinen tutkimuskeskus), Ruotsi (Tukholman yliopiston psykologian osasto) sekä Suomi (Työterveyslaitos).

Hankkeen päätavoitteena on ollut tutkia terveen organisaation myönteisiä tunnuspiirteitä sekä myönteisiä työtä koskevia hyvinvoinnin tiloja ja asenteita (mm. työn imua, työn merkityksellisyyttä ja henkilökohtaista kasvua työssä) ennustavia tekijöitä. Ensimmäisenä projektivuonna kehitimme kyselyn työtä ja työoloja koskevien myönteisten tekijöiden, työhyvinvoinnin ja mm. myönteisen organisaatiotoiminnan arvioimiseksi. Kysely on käännetty ruotsiksi ja norjaksi. Projektin toisena vuotena suunnittelimme aineistonkeruun ja testasimme kyselylomakkeen valituissa yrityksissä Norjassa ja Ruotsissa. Näihin tutkimusaineistoihin pohjautuvien tulosten pohjalta validoimme pohjoismaisen positiivisen organisaatiopsykologia-kyselyn, N-POP:in (Nordic Questionnaire on Positive Organizational Psychology). N-POP julkaistaan käsillä olevassa raportissa.

Johdannossa esitellään kyselyn kehittämisen teoreettinen tausta. Esittelemme hankkeessa kehitetyn tutkimusmallin sekä kuvailemme kyselyssä tarkastellut myönteiset käsitteet. Esittelemme myös hankkeen yksityiskohtaisemmat tavoitteet. Menetelmäluvussa esittelemme validoinnissa käytetyt norjalaiset ja ruotsalaiset tutkimusaineistot ja aineistonkeruun. Tulosluvussa raportoimme N-POP-kyselyn summamuuttujien reliabiliteetit (sisäinen yhdenmukaisuus) sekä tarkastelemme mittareiden rakennevaliditeettia keskinäisten korrelaatiokertoimien avulla. Pohdinnassa palaamme tutkimuksen teoreettiseen malliin, ja päättelemme kyselyn mittareiden olevan sisäisesti yhdenmukaisia sekä valideja. N-POP on luotettava menetelmä erityyppisten organisaatioiden psykososiaalisten voimavara- ja muiden työolotekijöiden, myönteisten työhyvinvoinnin tilojen ja asenteiden sekä monien kyselyssä sovellettujen organisatoristen ja yksilöllisten tulosmuuttujien arvioimiseksi. Lisäksi pohdintaluvussa esittelemme, milloin ja miten menetelmää voivat kaikki kiinnostuneet käyttää omassa työssään. Loppupäätelmämme on, että työn ja työolojen myönteiset voimavarat, työntekijöiden aito hyvinvointi ja terveys sekä tuottavuus voivat esiintyä optimaalisesti rinnakkain, niin että henkilöstön työn imu ja muu hyvinvointi sekä terve ja tuottava organisaatio mahdollistavat toinen toisensa. 



\section{Sammendrag}

Denne rapporten er basert på resultater fra det Nordiske prosjektet «Building engagement and healthy organisations». Prosjektet er finansiert av Nordisk Ministerråd. Prosjektet er et samarbeid mellom forskere fra Danmark, Finland, Norge og Sverige.

Hovedformålet med prosjektet var å undersøke prediktorer for positive jobbrelaterte tilstander og holdninger, f.eks. jobbengasjement, mening i arbeidet og personlig vekst, og sunne organisasjoner. I prosjektets første år utviklet og designet vi et spørreskjema for å måle positive faktorer i arbeidet, individuell well-being og positiv organisatorisk jobbutførelse. Spørreskjemaet ble oversatt til både norsk og svensk. I prosjektets andre år planla vi og gjennomførte en pilotstudie i Norge og Sverige, hvor vi sendte ut spørreskjema til utvalgte organisasjoner i de respektive landene. De svenske respondentene var ansatte i en medium stor bank og jobbet innen finans og det private marked, utvikling og administrasjon $(\mathrm{N}=180)$. Det norske spørreskjemaet ble fordelt til åtte ulike arbeidsplasser. Disse åtte arbeidsplassene ble kategorisert inn i tre ulike kategorier: revisjon $(n=44)$, sykehus $(n=69)$ og høgskole $(n=89)$. Det totale norske utvalget besto av 202 respondenter. Resultatene fra disse spørreskjemaundersøkelsene ble brukt som bakgrunn for en første validering av The Nordic Questionnaire on Positive Organizational Psychology (N-POP) som blir publisert i denne rapporten.

Rapportens introduksjonsdel tilbyr en redegjørelse av den teoretiske bakgrunnen for utviklingen av spørreskjemaet. Beskrivelsen inkluderer en arbeidsmodell, samt en mer detaljert beskrivelse av konseptene som blir brukt i spørreskjemaet. Formålene med prosjektet er også beskrevet på en mer detaljert måte. Metodedelen inkluderer en beskrivelse av utvalgene i Norge og Sverige som ble brukt som underlag i valideringsstudien. Både samplingsprosedyren og utvalget er beskrevet i denne seksjonen. I resultatdelen blir både resultater vedrørende målene i spørreskjemaet sin reliabilitet og validitet rapportert. konstruktvaliditet rapporteres gjennom korrelasjonsresultater mellom de inkluderte begrepene i arbeidsmodellen. I diskusjonsdelen er arbeidsmodellen en sentral del av diskusjonen, og det blir konkludert med at resultatene viser at spørreskjemainstrumentet (N-POP) viser god reliabilitet og validitet når det gjelder måling av det psykososiale arbeidsmiljøet, positive 
arbeidsrelaterte tilstander og holdninger, samt flere organisatoriske og individuelle utfallsvariabler. I tillegg gis det informasjon og råd om når det anbefales å bruke spørreskjemaet, og hvordan man bør bruke det. Tilslutt konkluderes det oppsummeringsvis med at begrepene positive prediktorer, individuell well-being, helse og organisatorisk produktivitet ser ut til å eksistere sammen i en optimal situasjon hvor well-being på et individnivå eksisterer side ved side med effektive og produktive organisasjoner. 


\title{
9. Appendix A. Descriptions of concepts underlying the scales included in the N-POP
}

\author{
Description of Cooperation \\ Cohesion has traditionally been defined as a unitary construct (Mullen \& \\ Copper, 1994; Zaccaro, 1991) and tended to reflect Festinger's (1950) \\ notion that cohesion is "the total field of forces which act on members to \\ remain in the group. These forces may depend on the attractiveness or \\ unattractiveness of either the prestige of the group, members of the \\ group, or the activities in which the group engages" (p. 274). In this pro- \\ ject cooperation was measured by three items based on the measurement \\ of cohesion in work teams from Carless and DePaola (2000) and three \\ items measuring "social community" from COPSOQ (Pejtersen, Kristensen, \\ Borg, \& Bjørner, 2010) that were collapsed into a single scale.
}

\section{Description of Innovative Climate}

Innovative climate is part of organisational culture and entails the existence of continuous improvement practices in learning organisations. Innovative climate is measured with a three-item scale from the QPSNordic (Dallner et al., 2000)

\section{Description of Job Demands}

Job demands are those aspects of the psychosocial work environment that "have to be done" and are associated with risk of psychological or physical exertion (cf. Schaufeli \& Bakker, 2004). Job demands can constitute quantitative demands, decision-making demands or learning demands. Job demands are measured with a composite seven-item scale culled from the QPS-Nordic (Dallner et al., 2000).

\section{Description of Job Performance}

Three specific aspects of positive job performance have often been distinguished. In-role performance refers to role-prescribed activities that contribute to formal task requirements and directly serve the goals of the organisation (Goodman \& Svyantek, 1999). Extra-role performance, on the other hand, refers to altruistic and other not so formally prescribed activities that support the organisational, social, and psychological work environment and are based on employee predisposition and volition (Goodman \& Svyantek, 1999). Finally, personal initiative (PI) refers to active and initiative-taking behaviour that goes beyond the 
formal requirements of work. More specifically, PI: (1) is consistent with the organisation's mission, (2) has long-term focus, (3) is goal-directed and action-oriented, (4) is persistent when facing barriers or setbacks, and (5) is self-starting and proactive (Frese, Fay, Hilburger, Leng, \& Tag, 1997). Here we used the following scales to measure various aspects of job performance. We used the shortened scales by Goodman and Svyantek (1999) to measure in-role performance with three items and extra-role performance with four items. In addition, we used a shortened four-item version of personal initiative by Frese et al. (1997).

\section{Description of Life Satisfaction}

Life satisfaction is identified as a distinct construct, and represents a cognitive and global evaluation of the quality of one's life as a whole. Life satisfaction is measured with the five-item Satisfaction with Life Scale (SWLS) (Diener, Emmons, Larsen, \& Griffin, 1985)

\section{Description of Meaning at Work}

Meaning at work relates to the sense that employees subjectively make of their work tasks as a central component in experiencing meaning at work (Wrzesniewski, 2003). A central feature in experiences of meaning at work is the experience of possibilities to express oneself through work activities (Chalofsky, 2003), and, accordingly, experiences of congruency between personal values and work activities may help to affirm individual identity and enhance individual identification with concrete work tasks (Sagiv, Roccas, \& Hazan, 2004; Wrzesniewski, 2003). Indeed, individuals experience meaning at work when the work roles and work context are considered purposeful and significant (Pratt \& Ashforth, 2003), thereby affirming central aspects of individual identity and satisfying basic psychological needs, such as self-acceptance, autonomy, and purpose in life (Baumeister \& Vohs, 2005; Deci \& Ryan, 2000; Keyes, 2007). Experience of meaning at work is measured with a six-item scale. Three items were taken from COPSOQ (Pejtersen et al., 2010) and three items were developed by researchers at the National Research Centre for the Working Environment, Denmark.

\section{Description of Optimism}

Optimism implies positive expectations about the future (Scheier, Carver, \& Bridges, 1994). Dispositional optimism is defined as generalised positive expectations of the future. Optimists expect good things to happen to them and pessimists expect the opposite (Carver \& Scheier, 2002). Carver and Scheier (2002) define optimism as the global generalised tendency to believe that one will generally experience good outcomes in life rather than bad ones. In this project optimism was measured by three items taken from the Life Orientation Test (Scheier et al., 1994). 


\section{Description of Organisational Justice}

According to Colquitt (2001) it is possible to differentiate between four types of organisational justice, namely distributive, procedural, informational and interpersonal justice. In the present report we provide a measure of procedural justice. A central point of the concept of procedural justice is that decisions in organisations are results of fair decision-making processes, where all relevant parties are heard before a decision is taken (cf. Thibaut \& Walker, 1975). Organisational justice is measured by a fouritem scale taken from COPSOQ (Pejtersen et al., 2010).

\section{Description of Organisational Commitment}

Organisational commitment can be construed as a force that binds an individual to an organisation and elicits behaviour relevant to the organisation (Meyer et al., 2006). Meyer and Allen (1997) identify three distinct forms of organisational commitment: affective commitment, continuance commitment, and normative commitment. In this report, we measure the affective commitment component, and the affective organisational commitment of employees refers to "... the employee's emotional attachment to, identification with, and involvement in the organization. Employees with a strong affective commitment continue employment with the organization because they want to do so"(Meyer \& Allen, 1997, p. 11). Another conceptualisation of organisational commitment points towards " ... a strong belief in and acceptance of the organization's goals and values,[...] a willingness to exert considerable effort on behalf of the organization, [...] and a definite desire to maintain organizational membership" (Porter, Steers, Mowday, \& Boulian,1974, p. 604). These two conceptualisations of AOC thus point towards the employee's attachment to his or her work organisation, where participation in organisational life becomes an end in itself and is increasingly characterised by intrinsic motivation (Deci \& Ryan, 1985) as the feelings of AOC intensify (Meyer \& Herscovitch, 2001). Organisational commitment is measured by a four-item scale taken from COPSOQ (Pejtersen et al., 2010).

\section{Description of Personal Growth and Personal Growth Composite}

Well-being researchers often distinguish between hedonic and eudaimonic dimensions. Hedonic well-being is usually associated with life satisfaction and emotions like pleasure and enjoyment, whereas eudaimonia concerns personal growth and emotions like engagement, interest and inspiration. Personal growth is commonly defined as the tendency to realise one's potentialities, to be open to new experiences, and to continuously develop oneself as a person (e.g. Ryan, Huta, \& Deci, 2008; Waterman, 1993, 2008).

Using theoretical evaluations in psychological and philosophical traditions, Vitters $\varnothing$ and colleagues have operationalised personal growth to involve curiosity, complexity, competence and absorption. The Personal Growth Composite (PGC) has proven to be a valid and reliable measure 
of eudaimonia and to be distinguishable from hedonic well-being measures. For example, in one study Vittersø and Søholt (2011) used a longitudinal design to demonstrate that the PGC measured at Time 1 predicted the experience of interest as measured approximately two months later (T2). In the same study, the Satisfaction With Life Scale (SWLS; Diener et al., 1985) measured at T1 predicted pleasant episodes at $\mathrm{T} 2$ but no interesting episodes at T2. In another study, PGC was associated with positive affect in difficult and unfamiliar situations whereas the SWLS was associated with positive affect in simple and familiar situations (Vittersø, Søholt, Hetland, Thorsen, \& Røysamb, 2010). The PGC has proven to be both reliable and valid in both the above-mentioned studies, as well as in several others (e.g. Straume \& Vittersø, 2012; Træen, Martinussen, Vittersø, \& Saini, 2009). The PGC combines four sub-dimensions from established inventories (see Vittersø, in press, for further details).

\section{Description of Positive Feedback}

Feedback from the job itself is defined as the degree to which carrying out the work activities required by the job results in the employee obtaining direct and clear information about the effectiveness of his or her performance (Hackman \& Oldham, 1975). In this project positive feedback was measured by three items taken from the Job Diagnostic Survey of Hackman and Oldham (1975) and three items taken from the Healthy Orgnization Barometer (Lindström, 1997; Lindström et al., 2000).

\section{Description of Role Conflicts}

Role conflicts can be characterised as a psychological job demand that arises when employees are placed in a situation with the simultaneous occurrence of two (or more) sets of pressures. This situation means that compliance with one would make it more difficult to comply with the other (Warr, 1987), and accordingly role conflicts are characterised as hindering job demand to the extent that they block the performance of the job tasks (cf. Podsakoff, LePine \& LePine, 2007). Role conflicts are measured with a three-item scale from COPSOQ (Pejtersen et al., 2010).

\section{Description of Skill Variety}

The concept of skill variety taps into the possibilities of employees being able to utilise and develop their skills while performing their job functions. Skill variety is measured with a two-item scale from QPS-Nordic (Dallner et al., 2000).

\section{Description of Trust}

The willingness of a party to be vulnerable to the actions of another party based on the expectation that the other will perform a particular action important to the trustor, irrespective of the ability to monitor or control that other party (cf. Mayer, Davis, \& Schoorman, 1995). In organ- 
isational research it is common practice to distinguish between vertical trust - i.e. trust across hierarchies - and horizontal trust - i.e. trust within hierarchies (cf. Kristensen, Hasle, \& Pejtersen, 2008). In the present questionnaire we measure the vertical trust of employees towards their managers with a four-item scale from COPSOQ (Pejtersen et al., 2010).

\section{Description of Work Engagement}

Work engagement is defined as a positive, fulfilling, affectivemotivational work-related state of well-being that is characterized by vigor, dedication, and absorption. Rather than a momentary and specific state, engagement refers to a more persistent and pervasive affectivecognitive state that is not focused on any particular object, event, individual, or behavior (Schaufeli \& Bakker, 2003; Schaufeli, Salanova, González-Romá, \& Bakker, 2001).

In this project, work engagement was measured by three items taken from the Utrecht Work Engagement Scale (UWES) (Schaufeli \& Bakker, 2003).

\section{Description of Work-Family and Family-Work Enrichment}

Work-family literature today acknowledges that in addition to possible conflicts between the two domains, there can also be positive interaction between work and family and combining work and family can have positive consequences (Wayne, Grzywacs, Carlson, \& Kacmar, 2007). Greenhaus and Powell (2006, p.73) define work-family enrichment as: "the extent to which experiences in one role improve the quality of life in the other role", referring to a transmission of positive experiences from one role to another. Similarly to work-family conflict, enrichment can also be divided into work-family enrichment (WFE) - positive influence of the work role on the family role - and family-work enrichment (FWE) positive impact of the family role on the work role - (Frone, 2003). In a previous three-year follow-up study we found that WFE positively predicted work engagement and vice versa, and in addition that FWE positively predicted marital satisfaction (Hakanen, Peeters, \& Perhoniemi, 2011). In this project both WFE and FWE were measured by three items from Grzywacs and Marks (2000).

\section{References}

Baumeister, R. F., \& Vohs, K. D. (2005). The Pursuit of Meaningfulness in Life. In R. Snyder \& S. J. Lopez (Eds.), Handbook of positive psychology (pp. 608-618). New York, NY: Oxford University Press. .

Carless, S.A., \& De-Paola, C. (2000). The measurement of cohesion in work teams. Small Group Research, 31(1), 71-88.

Carver, C. S., \& Scheier, M. F. (2002). Optimism. In C. R. Snyder \& S. J. Lopez (Eds.), Handbook of positive psychology (pp. 231-243). New York, NY: Oxford University Press.

Chalofsky, N. (2003). An emerging construct of meaningful work. Human Resource Development International, 6(1), 69-83. 
Colquitt, J.A. (2001). On the dimensionality of organizational justice: A construct validation of a measure. Journal of Applied Psychology, 86, 386-400.

Dallner, M., Elo, A.-L., Gamberale, F., Hottinen, V., Knardahl, S., Lindström, K. \& Orhede, E. (2000). Validation of the General Nordic Questionnaire (QPS Nordic) for psychological and social factors at work. (Nord 2000:12). Copenhagen: Nordic Council of Ministers.

Deci, E. L., \& Ryan, R. M. (2000). "The "what" and "why" of goal pursuits: Human needs and the self-determination of behavior. Psychological Inquiry, 11(4), 227-268.

Deci, E. L. \& Ryan, R. M. (1985). Intrinsic motivation and self-determination in human behavior. New York, NY: Plenum.

Diener, E., Emmons, R. A., Larsen, R. J., \& Griffin, S. (1985). The Satisfaction with Life Scale. Journal of Personality Assessment, 49, 71-75.

Festinger, L. (1950). Informal social communication. Psychological Review, 57, 271-282.

Frese, M., Fay, D., Hilburger, T., Leng, K., \& Tag, A. (1997). The concept of personal initiative: operationalization, reliability and validity in two German samples. Journal of Occupational and Organizational Psychology, 70, 139-161.

Frone, M. R. (2003). Work-family balance. In J. C. Quick \& L. E. Tetrick (Eds.), Handbook of occupational health psychology (pp. 143-162). Washington DC: American Psychological Association.

Goodman, S. A., \& Svyantek, D. J. (1999). Person-organization fit and contextual performance: Do shared values matter? Journal of Vocational Behavior, 55, 254-275.

Greenhaus, J. H., \& Powell, G. N. (2006). When work and family are allies: A theory of work-family enrichment. Academy of Management Review, 31, 72-92.

Grzywacz, J. G., \& Marks, N. F. (2000). Reconceptualizing the work-family interface: an ecological perspective on the correlates of positive and negative spillover between work and family. Journal of Occupational Psychology, 5, 111-126.

Hackman, J.R., \& Oldham, G.R. (1975). Development of the Job Diagnostic Survey. Journal of Applied Psychology, 60, 159-170.

Hakanen, JJ., Peeters, M., \& Perhoniemi, R. (2011). Enrichment processes and gain spirals at work and at home: A three-year cross-lagged panel study. Journal of Occupational and Organizational Psychology: A Special Section for Extending the Boundaries of Psychological Resource Theories in Organizations, 84, 8-30.

Keyes, C. L. M. (2007). Promoting and protecting mental health as flourishing: A complementary strategy for improving national mental health. American Psychologist, 62(2), 95-108.

Kristensen, T.S., Hasle, P., \& Pejtersen, J.H. (2008). Virksomhedens sociale kapital en ny indfaldsvinkel til det psykiske arbejdsmiljø? [The social capital of the organisation - a new approach to the psychosocial work environment?]. Tidsskrift for Arbejdsliv, 10, 30-45.

Lindström, K. (1997). Assessing and promoting healthy work organizations. In P. Seppälä, T. Luopajärvi, C. Nygard, \& M. Mattila (Eds.), From experience to innovation (pp. 504-506). Helsinki: Finnish Institute of Occupational Health

Lindström, K., Hottinen, V., \& Bredenberg, K. (2000). Työilmapiiri- ja hyvinvointibarometri. [The Healthy Organization Barometer]. Helsinki: Työterveyslaitos.

Mayer, R., Davis, J.H., \& Schoorman F.D. (1995). An integral model of organizational Trust. Academy of Management Review, 20, 709-734.

Meyer, J. P., Becker, T. E., \& Van Dick, R. (2006). Social Identities and Commitments at Work: Toward an Integrative Model. Journal of Organizational Behavior, 27, 665-683.

Meyer, J. P., \& Allen, N. J. (1997). Commitment in the workplace. Theory, research, and application. Thousand Oaks, CA: SAGE Publications.

Meyer, J. P., Becker, T. E., \& Van Dick, R. (2006). Social identities and commitments at work: Toward an integrative model. Journal of Organizational Behavior, 27, 665-683.

Meyer, J. P., \& Herscovitch, L. (2001). Commitment in the workplace: Toward a general model. Human Resource Management Review, 11, 299-326. 
Mullen, B., \& Copper, C. (1994). The relations between group cohesiveness and performance: An integration. Psychological Bulletin, 115, 210-227.

Pejtersen, J. H., Kristensen, T. S., Borg, V., \& Bjørner, J. B. (2010). The second version of Copenhagen Psychosocial Questionnaire (COPSOQII). Scandinavian Journal of Public Health, 38(suppl 3), 8-24.

Podsakoff, N. P., LePine, J. A., \& LePine, M. A. (2007).Differential challenge stressorhindrance stressor relationships with job attitudes, turnover intentions, turnover, and withdrawal behavior: A meta-analysis. Journal of Applied Psychology, 92(2), 438-454.

Porter, L. W., Steers, R. M., Mowday, R. T., \& Boulian, P. V. (1974). Organizational commitment, job satisfaction, and turnover among psychiatric technicians. Journal of Applied Psychology, 59, 603-609.

Pratt, M. G., \& Ashforth, B. E. (2003). Fostering meaningfulness in working and at work. In K. S. Cameron, J. E. Dutton, \& R. E. Quinn (Eds.), Positive organizational scholarship. Foundations of a new discipline (pp. 309-327). San Francisco, CA: Berett-Kohler.

Ryan, R.M., Huta, V.A., \& Deci, E.L. (2008). Living well: A self-determination theory perspective on eudaimonia. Journal of Happiness Studies, 9, 139-170.

Sagiv, L., Roccas, S., \& Hazan, O. (2004). Value pathways to well-Being: Healthy values, valued goal attainment, and environmental congruence. In P. A. Linley \& S. Joseph (Eds.), Positive psychology in practice (pp. 68-85). Hoboken, NJ: John Wiley and Sons.

Schaufeli, W.B., \& Bakker, A.B. (2003). Utrecht Work Engagement Scale: Preliminary manual. The Netherlands: Department of Psychology, Utrecht University.

Schaufeli, W. B., \& Bakker, A. (2004). Job demands, job resources, and their relationship with burnout and engagement: a multi-sample study. Journal of Organizational Behavior, 25, 293-315.

Schaufeli, W.B., Salanova, M., González-Romá, V., \& Bakker, A.B. (2001). Themeasurement of engagement and burnout: A confirmatory analytic approach. Journal of Happiness Studies, 3, 71-92.

Scheier, M. F., Carver, C. S., \& Bridges, M. W. (1994). Distinguishing optimism from neuroticism (and trait anxiety, self-mastery, and self-esteem): A reevaluation of the Life Orientation Test. Journal of Personality and Social Psychology, 67(6), 1063-1078.

Straume, L. V. \& Vittersø, J. (2012). Happiness, inspiration and the fully functioning person: Separating hedonic and eudaimonic well-being in the work place. Journal of Positive Psychology, 7, 387-398.

Thibaut, J., \& Walker, L. (1975). Procedural justice: A psychological analysis. Hillsdale, NJ: Erlbaum.

Træen, B., Martinussen, M., Vittersø, J., \& Saini, S. (2009). Sexual orientation and quality of life among university students from Cuba, Norway, India and South Africa. Journal of Homosexuality, 56, 655-669.

Vitters $\emptyset$, J. (in press). Personal growth. In A. Michalos (Ed.), Encyclopedia of quality of life studies. New York, NY: Springer

Vittersø, J., \& Søholt, Y. (2011). Life satisfaction goes with pleasure and personal growth goes with interest: Further arguments for separating hedonic and eudaimonic well-being. Journal of Positive Psychology, 6, 326-335.

Vittersø, J., Søholt, Y., Hetland, A., Thorsen, I. A., \& Røysamb, E. (2010). Was Hercules happy? Some answers from a functional model of human well-being. Social Indicators Research, 95, 1-18.

Warr, P. (1987). Work, unemployment and mental health. Oxford: Oxford University Press.

Waterman, A. S. (1993). Two conceptions of happiness: Contrasts of personal expressiveness (eudaimonia) and hedonic enjoyment. Journal of Personality and Social Psychology, 64, 678-691. 
Waterman, A. S. (2008). Reconsidering happiness: A eudaimonist's perspective. Journal of Positive Psychology, 3, 234-252.

Wayne, J. H.,Grzywacz, J. G., Carlson, D. S., \& Kacmar, K. M. (2007). Work-family facilitation: A theoretical explanation and model of primary antecedents and consequences. Human Resource Management Review, 17, 63-76.

Wrzesniewski, A. (2003). Finding positive meaning in work. In K. S. Cameron, J. E. Dutton, \& R. E. Quinn (Eds.), Positive organizational scholarship. Foundations of a new discipline (pp. 296-308). San Francisco, CA: Berett-Kohler Publishers.

Zaccaro, S. (1991). Nonequivalent associations between forms of cohesiveness and group-related outcomes: Evidence for multidimensionality. Journal of Social Psychology, 131, 387-399. 


\section{Appendix B Scale information}

Means and standard deviations are based on the Norwegian $(\mathrm{N}=202)$ and Swedish $(\mathrm{N}=180)$ datasets used in developing and validating the Nordic Positive Organisational Psychology Questionnaire (N-POP)

\section{Job and personal resources and job demands}

\begin{tabular}{|c|c|c|c|}
\hline Item & & Mean & $\begin{array}{l}\text { Standard } \\
\text { deviation }\end{array}$ \\
\hline 1 & $\begin{array}{l}\text { Are your skills and knowledge useful in your work? (Är dina kunskaper } \\
\text { och färdigheter till nytta I ditt arbete?) }\end{array}$ & 4.23 & .79 \\
\hline 2 & $\begin{array}{l}\text { Do you consider your work meaningful? (Tycker du att ditt arbete är } \\
\text { meningsfullt?) }\end{array}$ & 4.29 & .76 \\
\hline Scale & & 4.27 & .66 \\
\hline \multicolumn{4}{|c|}{$\begin{array}{l}\text { Reference: Dallner, M., Elo, A. } \\
\text { Orhede, E. (2000). Validation } \\
\text { factors at work. (Nord 2000:12 }\end{array}$} \\
\hline Item & & Mean & $\begin{array}{l}\text { Standard } \\
\text { deviation }\end{array}$ \\
\hline 3 & $\begin{array}{l}\text { The work itself provides me with information about how well I am doing } \\
\text { (I mitt arbete finns många tillfällen att bedöma hur väl jag klarar arbetet) }\end{array}$ & 3.74 & .87 \\
\hline 4 & $\begin{array}{l}\text { My manager provides me with constant feedback about how I am doing } \\
\text { (Mina chefer talar ofta om för mig hur de anser att jag klarar mitt arbete) }\end{array}$ & 3.00 & 1.18 \\
\hline 5 & $\begin{array}{l}\text { The results of my efforts are clearly visible and identifiable (Det är lätt för } \\
\text { mig att se mitt arbetes effekter) }\end{array}$ & 3.77 & .80 \\
\hline 6 & $\begin{array}{l}\text { Does your superior appreciate your work? (Min arbetsledare uppskattar } \\
\text { mitt arbete) }\end{array}$ & 3.73 & 1.01 \\
\hline 7 & $\begin{array}{l}\text { Is your work appreciated outside the workplace? (Mitt arbete uppskattas } \\
\text { utanför arbetsplatsen) }\end{array}$ & 3.52 & .90 \\
\hline 8 & $\begin{array}{l}\text { Do you yourself consider your work important and significant? (Jag anser } \\
\text { själv att mitt arbete är viktigt) }\end{array}$ & 4.31 & .69 \\
\hline Scale & & 3.68 & .61 \\
\hline \multicolumn{4}{|c|}{$\begin{array}{l}\text { Hackman, J.R., Oldham, G.R. (1975). Development of the Job Diagnostic Survey. Journal of Applied Psychology, } \\
\text { 60, 159-170. } \\
\text { The last three items were taken from Lindström, K. (1997). Assessing and promoting healthy work organiza- } \\
\text { tions. In P. Seppälä, T. Luopajärvi, C. Nygard, \& M. Mattila (Eds.), From experience to innovation (pp. 504-506). } \\
\text { Helsinki: Finnish Institute of Occupational Health and Lindström, K., Hottinen, V., \& Bredenberg, K. (2000). } \\
\text { Työilmapiiri- ja hyvinvointibarometri. [The Healthy Organization Barometer]. Helsinki: Työterveyslaitos. }\end{array}$} \\
\hline
\end{tabular}


Table 3. Cooperation

\begin{tabular}{lllr}
\hline Item & & Mean & $\begin{array}{r}\text { Standard } \\
\text { deviation }\end{array}$ \\
\hline 9 & $\begin{array}{l}\text { Our team is united in trying to reach its goals for performance (Vår arbets- } \\
\text { grupp är ense när det gäller satsningar för att nå våra prestationsmål) }\end{array}$ & 3.77 & .94 \\
10 & $\quad \begin{array}{l}\text { I am happy with my team's commitment to the task (Jag är nöjd med min } \\
\text { arbetsgrupps insats för att nå målen) (Adapted from original item) }\end{array}$ & 3.94 & .81 \\
11 & $\begin{array}{l}\text { The team gives me enough opportunities to improve my personal perfor- } \\
\text { mance (Jag har stora möjligheter att förbättra mina personliga prestationer } \\
\text { I den här arbetsgruppen) (Adapted from original item) }\end{array}$ & 3.53 & .95 \\
12 & $\quad \begin{array}{l}\text { Is there a good atmosphere between you and your colleagues? (Det är god } \\
\text { stämning mellan mig och mina kollegor) }\end{array}$ & 4.27 & .72 \\
13 & $\quad \begin{array}{l}\text { Is there good co-operation between the colleagues at work? (Det är gott } \\
\text { samarbete på min arbetsplats) }\end{array}$ & 3.99 & .96 \\
14 & $\begin{array}{l}\text { Do you feel part of a community at your place of work? (Jag känner att jag } \\
\text { är en del av gruppen på min arbetsplats) }\end{array}$
\end{tabular}

Reference: The three first items were taken from Carless, S.A., De-Paola, C. (2000). The measurement of cohesion in work teams. Small Group Research. 31(1), 71-88. The three last items were taken from Pejtersen, J. H., Kristensen, T. S., Borg, V., and Bjørner, J. B. (2010), "The second version of Copenhagen Psychosocial Questionnaire (COPSOQII)", Scandinavian Journal of Public Health, 38(suppl 3), 8-24.

\section{Table 4. Trust}

\begin{tabular}{|c|c|c|c|}
\hline Item & & Mean & $\begin{array}{l}\text { Standard } \\
\text { deviation }\end{array}$ \\
\hline 15 & $\begin{array}{l}\text { Does the management trust the employees to do their work well? (Led- } \\
\text { ningen litar på att medarbetarna gör ett bra arbete) }\end{array}$ & 4.07 & .75 \\
\hline 16 & $\begin{array}{l}\text { Can you trust the information that comes from the management? (Man kan } \\
\text { lita på den information som kommer från ledningen) }\end{array}$ & 3.72 & .89 \\
\hline 17 & $\begin{array}{l}\text { Does the management withhold important information from the employees? } \\
\text { (Ledningen undanhåller viktig information från medarbetarna) (Reversed) }\end{array}$ & 2.45 & .99 \\
\hline 18 & $\begin{array}{l}\text { Are the employees able to express their views and feelings? (De anställda kan } \\
\text { fritt uttrycka sin mening och känsla) (det är "högt i tak" på arbetsplatsen) }\end{array}$ & 3.53 & 1.05 \\
\hline Scale & & 3.72 & .69 \\
\hline \multicolumn{4}{|c|}{$\begin{array}{l}\text { Reference: Pejtersen, J. H., Kristensen, T. S., Borg, V., and Bjørner, J. B. (2010), "The second version of Copenha- } \\
\text { gen Psychosocial Questionnaire (COPSOQII)", Scandinavian Journal of Public Health, 38(suppl 3), 8-24. }\end{array}$} \\
\hline
\end{tabular}

\section{Table 5. Justice}

\begin{tabular}{|c|c|c|c|}
\hline Item & & Mean & $\begin{array}{l}\text { Standard } \\
\text { deviation }\end{array}$ \\
\hline 19 & Are conflicts resolved in a fair way? (Konflikter löses på ett rättvist sätt) & 3.40 & .89 \\
\hline 20 & $\begin{array}{l}\text { Are employees appreciated when they have done a good job? (Anställda } \\
\text { visas uppskattning när de gör ett bra arbete) }\end{array}$ & 3.46 & .92 \\
\hline 21 & $\begin{array}{l}\text { Are all suggestions from employees treated seriously by the management? } \\
\text { (Förslag från de anställda tas seriöst av ledningen) }\end{array}$ & 3.46 & .87 \\
\hline 22 & Is the work distributed fairly? (Arbetsuppgifter fördelas rättvist) & 3.31 & .86 \\
\hline Scale & & 3.40 & .72 \\
\hline \multicolumn{4}{|c|}{$\begin{array}{l}\text { Reference: Pejtersen, J. H., Kristensen, T. S., Borg, V., and Bjørner, J. B. (2010), "The second version of Copenha- } \\
\text { gen Psychosocial Questionnaire (COPSOQII)", Scandinavian Journal of Public Health, 38(suppl 3), 8-24. }\end{array}$} \\
\hline
\end{tabular}


Table 6. Innovative climate

\begin{tabular}{|c|c|c|c|}
\hline Item & & Mean & $\begin{array}{l}\text { Standard } \\
\text { deviation }\end{array}$ \\
\hline 23 & $\begin{array}{l}\text { We regularly make improvements in our work (Det görs ständigt förbätt- } \\
\text { ringar i verksamheten) }\end{array}$ & 3.50 & .89 \\
\hline 24 & $\begin{array}{l}\text { Joint discussions are held concerning tasks, goals and how to attain them } \\
\text { (På min arbetsplats diskuterar vi tillsammans arbetsuppgifter, målsättning- } \\
\text { ar och sätt att uppnå målen) }\end{array}$ & 3.54 & .98 \\
\hline 25 & $\begin{array}{l}\text { We obtain feedback and suggestions for improvements from clients (Vi } \\
\text { skaffar oss feedback och förbättringsidéer från våra kunder) }\end{array}$ & 3.09 & .95 \\
\hline Scale & & 3.37 & .75 \\
\hline \multicolumn{4}{|c|}{$\begin{array}{l}\text { Reference: Hakanen, J.J., Bakker, A., \& Schaufeli, W. (2006). Burnout and engagement among teachers. Journal } \\
\text { of School Psychology, 43, 495-513. }\end{array}$} \\
\hline \multicolumn{4}{|c|}{ Table 7. Optimism } \\
\hline Item & & Mean & $\begin{array}{l}\text { Standard } \\
\text { deviation }\end{array}$ \\
\hline 26 & $\begin{array}{l}\text { In uncertain times, I usually expect the best )Under osäkra tider tror jag att } \\
\text { allt kommer att ordna sig) }\end{array}$ & 3.57 & .87 \\
\hline 27 & $\begin{array}{l}\text { I am always optimistic about my future (Jag ser alltid optimistiskt på } \\
\text { framtiden) }\end{array}$ & 3.69 & .81 \\
\hline 28 & $\begin{array}{l}\text { Overall, I expect more good things to happen to me than bad (Allmänt sett } \\
\text { väntar jag mig att det händer mig mera positiva än negativa saker) }\end{array}$ & 4.01 & .77 \\
\hline Scale & & 3.75 & .70 \\
\hline \multicolumn{4}{|c|}{$\begin{array}{l}\text { Reference: Life Orientation Test - Revised (LOT-R) Scheier, M. F., Carver, C. S., \& Bridges, M. W. (1994). } \\
\text { Distinguishing optimism from neuroticism (and trait anxiety, self-mastery, and self-esteem): A reevalutation of } \\
\text { the Life Orientation Test. Journal of Personality and Social Psychology, 67(6), 1063-1078. }\end{array}$} \\
\hline
\end{tabular}

\section{Table 8. Role conflicts}

\begin{tabular}{llc}
\hline Item & Mean & $\begin{array}{c}\text { Standard } \\
\text { deviation }\end{array}$ \\
\hline 29 & $\begin{array}{l}\text { Do you sometimes have to do things, which ought to have been done in a } \\
\text { different way? (Måste du utföra saker som du tycker skulle göras an- } \\
\text { norlunda?) }\end{array}$ & 2.80 \\
Are you asigned work tasks without being given the required resources to \\
complete your work tasks? (Får du arbetsuppgifter utan att få de resurser \\
som behövs för att utföra dem?)
\end{tabular}




\begin{tabular}{|c|c|c|c|}
\hline Item & & Mean & $\begin{array}{l}\text { Standard } \\
\text { deviation }\end{array}$ \\
\hline 32 & Do you have to work very fast? (Arbetar du i mycket högt tempo?) & 3.73 & .74 \\
\hline 33 & Does your work require quick decisions?(Kräver ditt arbete snabba beslut?) & 3.44 & .87 \\
\hline 34 & Are your work tasks too difficult for you? (Är dina arbetsuppgifter för svåra för dig?) & 2.02 & .76 \\
\hline 35 & $\begin{array}{l}\text { Does your work require maximum attention? (Kräver ditt arbete maximal uppmärk- } \\
\text { samhet?) }\end{array}$ & 3.95 & .79 \\
\hline 36 & Does your work require complex decisions? (Kräver ditt arbete komplicerade beslut?) & 3.26 & .84 \\
\hline 37 & $\begin{array}{l}\text { Do you perform work tasks for which you need more training? (Utför du arbetsuppgif- } \\
\text { ter som du skulle behöva mera utbildning för?) }\end{array}$ & 2.64 & .84 \\
\hline 38 & $\begin{array}{l}\text { Does your job require that you acquire new knowledge and new skills? (Kräver ditt } \\
\text { arbete att du skaffar dig nya kunskaper och färdigheter?) }\end{array}$ & 3.83 & .82 \\
\hline Scale & & 3.27 & .47 \\
\hline \multicolumn{4}{|c|}{$\begin{array}{l}\text { Reference: The first item is from Pejtersen, J. H., Kristensen, T. S., Borg, V., and Bjørner, J. B. (2010), "The second version of } \\
\text { Copenhagen Psychosocial Questionnaire (COPSOQII)", Scandinavian Journal of Public Health, 38(suppl 3), 8-24. The last six } \\
\text { items are from Dallner, M., Elo, A.-L., Gamberale, F., Hottinen, V., Knardahl, S., Lindström, K., Skogstad, A., \& Orhede, E. } \\
\text { (2000). Validation of the General Nordic Questionnaire (QPS Nordic) for psychological and social factors at work. (Nord } \\
\text { 2000:12). Copenhagen: Nordic Council of Ministers. }\end{array}$} \\
\hline
\end{tabular}




\section{Work-related states and attitudes}

Table 10. Personal growth

\begin{tabular}{|c|c|c|c|}
\hline \multicolumn{2}{|l|}{ Item } & \multirow{3}{*}{$\begin{array}{r}\text { Mean } \\
3.59\end{array}$} & \multirow{3}{*}{$\begin{array}{r}\begin{array}{r}\text { Standard } \\
\text { deviation }\end{array} \\
.86\end{array}$} \\
\hline & Curiosity & & \\
\hline 39 & $\begin{array}{l}\text { I enjoy tackling problems that are completely new to me (Jeg nyter og hanskes med } \\
\text { problem som er helt nye for meg) }\end{array}$ & & \\
\hline 40 & $\begin{array}{l}\text { I enjoy trying to solve complex problems (Jeg nyter å forsøke å løse kompliserte pro- } \\
\text { blemer) }\end{array}$ & 3.68 & .88 \\
\hline 41 & $\begin{array}{l}41 \text { I want my work to provide me with opportunities for increasing my knowledge and } \\
\text { skills (Jeg vil at mitt arbeid skal gi meg muligheter til å øke mine kunnskaper og ferdig- } \\
\text { heter) }\end{array}$ & 4.38 & .64 \\
\hline 42 & $\begin{array}{l}\text { Curiosity is the driving force behind much of what I do (Nysgjerrighet er drivkraften bak } \\
\text { mye av det jeg gjør) }\end{array}$ & 3.94 & .81 \\
\hline \multirow[t]{2}{*}{ Scale } & & 3.90 & .63 \\
\hline & Absorption & & \\
\hline 43 & $\begin{array}{l}\text { When I am participating in an activity, I tend to get so involved that I lose track of time (Når } \\
\text { jeg deltar i en aktivitet har jeg en tendens til å bli så involvert at jeg "glemmer tiden») }\end{array}$ & 3.50 & .91 \\
\hline 44 & $\begin{array}{l}\text { When I am actively interested in something, it takes a great deal to interrupt me (Når } \\
\text { jeg er intenst interessert i noe, skal det mye til for å avbryte meg) }\end{array}$ & 3.53 & .87 \\
\hline 45 & $\begin{array}{l}\text { My friends would describe me as someone who is "extremely intense" when in the } \\
\text { middle of doing something (Mine venner vil beskrive meg som «ekstremt intens» når } \\
\text { jeg er midt oppe i noe) }\end{array}$ & 2.91 & .99 \\
\hline \multirow[t]{2}{*}{ Scale } & & 3.32 & .79 \\
\hline & Complexity & & \\
\hline 46 & I believe in the importance of art (Jeg tror på betydningen av kunst) & 3.24 & 1.07 \\
\hline 47 & $\begin{array}{l}\text { I love to think up new ways of doing things (Jeg elsker å komme på nye måter å gjøre } \\
\text { ting på) }\end{array}$ & 3.66 & .85 \\
\hline 48 & I enjoy hearing new ideas (Jeg liker å høre om nye ideer) & 4.08 & .65 \\
\hline 49 & I can carry the conversation to a higher level (Jeg kan løfte en samtale til et høyere nivå) & 3.46 & .85 \\
\hline 50 & I prefer variety to routine (Jeg foretrekker variasjon fremfor rutine) & 3.90 & .88 \\
\hline \multirow[t]{2}{*}{ Scale } & & 3.67 & .59 \\
\hline & Competence & & \\
\hline 51 & I like to solve complex problems (Jeg liker å Iøse kompliserte problemer) & 3.15 & .87 \\
\hline 52 & I feel up to any task (Jeg mestrer de fleste oppgaver) & 3.77 & .60 \\
\hline 53 & I can perform a variety of tasks (Jeg kan utføre en rekke ulike oppgaver) & 4.07 & .53 \\
\hline 54 & I accept challenges (Jeg møter gjerne utfordrende oppgaver) & 3.93 & .61 \\
\hline 55 & I know how to apply my knowledge (Jeg vet hvordan jeg skal anvende mine kunnskaper) & 4.04 & .56 \\
\hline Scale & & 3.91 & .47 \\
\hline $\begin{array}{l}\text { Total } \\
\text { scale }\end{array}$ & Personal Growth & 3.69 & .51 \\
\hline $\begin{array}{l}\text { Refere } \\
\text { Spring }\end{array}$ & : Vitters $\varnothing$, J. (in press). Personal growth. In A. Michalos (Ed.), Encyc & dies. & lork: \\
\hline
\end{tabular}


Table 11. Work engagement

\begin{tabular}{|c|c|c|c|}
\hline Item & & Mean & $\begin{array}{l}\text { Standard } \\
\text { deviation }\end{array}$ \\
\hline 56 & $\begin{array}{l}\text { At my job, I feel strong and vigorous (Jag känner mig stark och energisk på } \\
\text { jobbet) }\end{array}$ & 4.00 & 1.36 \\
\hline 57 & I am enthusiastic about my job (Jag känner entusiasm över mitt jobb) & 4.06 & 1.42 \\
\hline 58 & $\begin{array}{l}\text { I am immersed in my work (När jag jobbar fokuserar jag helt och håller på uppgif- } \\
\text { ten) }\end{array}$ & 4.02 & 1.40 \\
\hline Scale & & 4.02 & 1.16 \\
\hline \multicolumn{4}{|c|}{$\begin{array}{l}\text { Reference: Utrecht Work Engagement Scale (UWES) Schaufeli, W., Bakker, A. B., \& Salanova, M. (2006). The Meas- } \\
\text { urement of Work Engagement With a Short Questionnaire: A Cross-National Study. Educational and Psychological } \\
\text { Measurement, 66, 701-716. }\end{array}$} \\
\hline
\end{tabular}

\section{Table 12. Meaning at work}

\begin{tabular}{|c|c|c|c|}
\hline Item & & Mean & $\begin{array}{l}\text { Standard } \\
\text { deviation }\end{array}$ \\
\hline 59 & Are your work tasks meaningful? (Är dina arbetsuppgifter meningsfulla?) & 4.09 & .73 \\
\hline 60 & $\begin{array}{l}\text { Do you feel motivated and engaged in your work? (Känner du dig motiverad och } \\
\text { engagerad i ditt arbete?) }\end{array}$ & 3.91 & .80 \\
\hline 61 & $\begin{array}{l}\text { Do you feel that you do an important job at work?(Känner du att du utför ett } \\
\text { betydelsefullt arbete?) }\end{array}$ & 4.05 & .74 \\
\hline 62 & My job is important for my self-esteem (Mitt jobb är viktigt för min självkänsla) & 3.84 & .88 \\
\hline 63 & $\begin{array}{l}\text { My work tasks make my life meaningful (Mina arbetsuppgifter gör att jag känner } \\
\text { mening med mitt liv) }\end{array}$ & 3.36 & .94 \\
\hline 64 & $\begin{array}{l}\text { My job is important for my personal development (Mitt jobb betyder mycket för } \\
\text { min personliga utveckling) }\end{array}$ & 3.69 & .89 \\
\hline 65 & My job means something for other people (Mitt arbete betyder något för andra) & 3.93 & .78 \\
\hline Scale & & 3.84 & .62 \\
\hline
\end{tabular}

Reference: The first three items are from Pejtersen, J. H., Kristensen, T. S., Borg, V., and Bjørner, J. B. (2010), “The second version of Copenhagen Psychosocial Questionnaire (COPSOQII)", Scandinavian Journal of Public Health, 38(suppl 3), 8-24. The last four items have been developed by researchers from the National Research Centre for the Working Environment from the National Work Cohort 2010 study.

\section{Table 13. Organizational commitment}

\begin{tabular}{|c|c|c|c|}
\hline Item & & Mean & $\begin{array}{l}\text { Standard } \\
\text { deviation }\end{array}$ \\
\hline 66 & $\begin{array}{l}\text { Do you enjoy telling other people about your workplace? (Jag berättar med } \\
\text { glädje om min arbetsplats för andra människor) }\end{array}$ & 3.65 & .93 \\
\hline 67 & $\begin{array}{l}\text { Would you recommend a good friend to apply for a job at your workplace? (Jag } \\
\text { skulle rekommendera en god vän att söka anställning på min arbetsplats) }\end{array}$ & 3.79 & 1.00 \\
\hline 68 & $\begin{array}{l}\text { How often do you think about looking for another job? (reversed) (Jag funderar } \\
\text { sällan på att söka ett annat arbete) }\end{array}$ & 3.28 & 1.19 \\
\hline 69 & $\begin{array}{l}\text { Do you think that your workplace is of great personal significance to you? (Jag } \\
\text { anser att min arbetsplats har stor betydelse för mig) }\end{array}$ & 3.81 & .85 \\
\hline Scale & & 3.63 & .76 \\
\hline $\begin{array}{l}\text { Refere } \\
\text { Psych }\end{array}$ & $\begin{array}{l}\text { Pejtersen, J. H., Kristensen, T. S., Borg, V., and Bjørner, J. B. (2010), "The secon } \\
\text { al Questionnaire (COPSOQII)", Scandinavian Journal of Public Health, 38(suppl }\end{array}$ & $\begin{array}{l}\text { on of } \\
4 .\end{array}$ & nhagen \\
\hline
\end{tabular}




\section{Individual and organizational outcomes}

Table 14. Personal initiative

\begin{tabular}{|c|c|c|c|}
\hline Item & & Mean & $\begin{array}{l}\text { Standard } \\
\text { deviation }\end{array}$ \\
\hline 70 & $\begin{array}{l}\text { Whenever something goes wrong, I search for a solution immediately (När } \\
\text { något går fel söker jag genast en lösning) }\end{array}$ & 4.28 & .63 \\
\hline 71 & $\begin{array}{l}\text { Whenever there is a chance to get actively involved, I take it (Om det bara } \\
\text { är möjligt vill jag aktivt vara med) }\end{array}$ & 3.92 & .77 \\
\hline 72 & $\begin{array}{l}\text { I take initiative immediately even when others don't (Jag tar genast } \\
\text { initiativet också när andra inte gör det) }\end{array}$ & 3.55 & .83 \\
\hline 73 & $\begin{array}{l}\text { Usually I do more than I am asked to do (I allmänhet gör jag mer än vad } \\
\text { som krävs av mig) }\end{array}$ & 3.81 & .75 \\
\hline Scale & & 3.89 & .57 \\
\hline \multicolumn{4}{|c|}{$\begin{array}{l}\text { Reference: Frese, M., Fay, D., Hilburger, T., Leng, K., \& Tag, A. (1997). The concept of personal initiative: } \\
\text { operationalization, reliability and validity in two German samples. Journal of Occupational and Organizational } \\
\text { Psychology, 70, 139-161. }\end{array}$} \\
\hline
\end{tabular}

\section{Table 15. In-role performance}

\begin{tabular}{llcc}
\hline Item & & Mean & $\begin{array}{c}\text { Standard } \\
\text { deviation }\end{array}$ \\
\hline $74 \quad \begin{array}{l}\text { I demonstrate expertise in all job-related tasks (Jag har kompetens inom } \\
\text { alla delområden i mitt arbete) }\end{array}$ & 3.87 & .80 \\
$75 \quad \begin{array}{l}\text { I am competent in all areas of the job, and handle tasks with proficiency } \\
\text { (Jag är kompetent inom alla arbetets olika delområden, och jag sköter } \\
\text { mina uppgifter med yrkesskicklighet) }\end{array}$ & 4.03 & .73 \\
$76 \quad \begin{array}{l}\text { I perform well in the overall job by carrying out tasks as expected (Jag } \\
\text { klarar av mitt arbete väl i dess helhet, genom att utföra arbetet så som det } \\
\text { skall göras) }\end{array}$ & 4.21 & .60 \\
Scale & & 4.03 & .63
\end{tabular}

Reference: Goodman, S. A., \& Svyantek, D. J. (1999). Person-organization fit and contextual performance: Do shared values matter. Journal of Vocational Behavior, 55, 254-275.

Table 16. Extra-role performance

\begin{tabular}{|c|c|c|c|}
\hline Item & & Mean & $\begin{array}{l}\text { Standard } \\
\text { deviation }\end{array}$ \\
\hline 77 & $\begin{array}{l}\text { I volunteer to do things not formally required by the job (Jag gör frivilligt } \\
\text { sådant som inte formellt krävs i mitt arbete) }\end{array}$ & 3.66 & .83 \\
\hline 78 & $\begin{array}{l}\text { I make innovative suggestions to improve the overall quality of our work- } \\
\text { place (Jag föreslår åtgärder för att förbättra kvaliteten på verksamheten på } \\
\text { vår arbetsplats) }\end{array}$ & 3.53 & .90 \\
\hline 79 & $\begin{array}{l}\text { I help others when their work load increases (assist others until they get } \\
\text { over the hurdles) (Jag hjälper andra om deras arbetsbörda ökar, tills de } \\
\text { kommit över det värsta) }\end{array}$ & 3.61 & .79 \\
\hline 80 & $\begin{array}{l}\text { I help other employees with their work when they have been absent (Jag } \\
\text { hjälper mina arbetskamrater med deras uppgifter) }\end{array}$ & 3.76 & .75 \\
\hline Scale & & 3.64 & .62 \\
\hline $\begin{array}{l}\text { Refere } \\
\text { sharec }\end{array}$ & $\begin{array}{l}\text { : Goodman, S. A., \& Svyantek, D. J. (1999). Person-organization fit and con } \\
\text { ues matter. Journal of Vocational Behavior, 55, 254-275. }\end{array}$ & perfo & ance: Do \\
\hline
\end{tabular}




\begin{tabular}{llcr} 
Table 17. Work-family enrichment & & Mean & $\begin{array}{c}\text { Standard } \\
\text { deviation }\end{array}$ \\
\hline Item & & .93 \\
\hline 81 & $\begin{array}{l}\text { The things I do at work help me deal with personal and practical issues at } \\
\text { home (Det jag gör i mitt arbete har jag nytta av när jag ska sköta människore- } \\
\text { lationer och praktiska angelägenheter i hemmet) }\end{array}$ & 2.79 \\
82 & $\begin{array}{l}\text { The things I do at work make me a more interesting person at home (Det jag } \\
\text { gör i mitt arbete gör mig också till en intressantare person hemma) }\end{array}$ & 2.79 & .89 \\
83 & $\begin{array}{l}\text { The skills I use on my job are useful for things I have to do at home (De } \\
\text { färdigheter jag använder i mitt arbete är till nytta också när jag sköter mina }\end{array}$ & 2.81 & .89 \\
hemangelägenheter) & & 2.80
\end{tabular}

Reference: Grzywacz, J. G., \& Marks, N. F. (2000). Reconceptualizing the work-family interface: an ecological perspective on the correlates of positive and negative spillover between work and family. Journal of Occupational Psychology, 5, 111-126.

\section{Table 18. Family-work enrichment}

\begin{tabular}{|c|c|c|c|}
\hline Item & & Mean & $\begin{array}{l}\text { Standard } \\
\text { deviation }\end{array}$ \\
\hline 84 & $\begin{array}{l}\text { Talking with someone at home helps me deal with problems at work )Arbets- } \\
\text { problem känns lättare att hantera när jag har någon att diskutera med } \\
\text { därhemma) }\end{array}$ & 3.13 & 1.00 \\
\hline 85 & $\begin{array}{l}\text { The love and respect I get at home makes me feel confident about myself at } \\
\text { work (Den kärlek och respekt jag får av min familj stärker mitt självförtro- } \\
\text { ende i arbetet) }\end{array}$ & 3.72 & 1.01 \\
\hline 86 & $\begin{array}{l}\text { My home life helps me relax and feel ready for the next day's work (Mitt } \\
\text { hemliv hjälper mig att koppla av och förbereda mig inför nästa arbetsdag) }\end{array}$ & 3.72 & 1.00 \\
\hline Scale & & 3.52 & .82 \\
\hline
\end{tabular}

Reference: Grzywacz, J. G., \& Marks, N. F. (2000). Reconceptualizing the work-family interface: an ecological perspective on the correlates of positive and negative spillover between work and family. Journal of Occupational Psychology, 5, 111-126.

\section{Table 19. Life satisfaction}

\begin{tabular}{|c|c|c|c|}
\hline Item & & Mean & $\begin{array}{l}\text { Standard } \\
\text { deviation }\end{array}$ \\
\hline 87 & $\begin{array}{l}\text { In most ways my life is close to my ideal (Mitt liv är på många sätt nära det } \\
\text { som är idealiskt för mig) }\end{array}$ & 5.03 & 1.30 \\
\hline 88 & $\begin{array}{l}\text { The conditions of my life are excellent (Mina levnadsförhållanden är mycket } \\
\text { goda) }\end{array}$ & 5.64 & 1.09 \\
\hline 89 & I am satisfied with my life (Jag är nöjd med mitt liv) & 5.72 & 1.07 \\
\hline 90 & $\begin{array}{l}\text { So far I have gotten the important things I want in life (Hittills har jag uppnått } \\
\text { det som varit viktigt för mig att uppnå) }\end{array}$ & 5.43 & 1.19 \\
\hline 91 & $\begin{array}{l}\text { If I could live my life over, I would change almost nothing (Om jag kunde leva } \\
\text { om mitt liv skulle jag inte göra mycket annorlunda) }\end{array}$ & 4.77 & 1.49 \\
\hline Scale & & 5.31 & 1.01 \\
\hline $\begin{array}{l}\text { Refer } \\
\text { Journ }\end{array}$ & $\begin{array}{l}\text { Diener, E., Emmons, R. A., Larsen, R. J., \& Griffin, S. (1985). The Satisfaction } \\
\text { Personality Assessment, 49, 71-75. }\end{array}$ & h Life $S$ & \\
\hline
\end{tabular}


Work-family conflicts

Do the demands of your work interfere with your home and family life? (Påverkar kraven i ditt arbete ditt hem och familjeliv på ett negativt sätt?) related activities? (Påverkar kraven i ditt hem/din familj ditt arbete på ett negativt sätt?)

Reference: Dallner, M., Elo, A.-L., Gamberale, F., Hottinen, V., Knardahl, S., Lindström, K., Skogstad, A., \& Orhede, E. (2000). Validation of the General Nordic Questionnaire (QPS Nordic) for psychological and social factors at work. (Nord 2000:12). Copenhagen: Nordic Council of Ministers.

\section{Recovery and relaxation}

I feel rested and recuperated when I start working in the morning (Jag känner mig utvilad och återhämtad när jag börjar arbetet på morgonen) arbetsdagen arbetsdagen) weeks 'leave' from work /vacation (Jag känner du mig utvilad och återhämtad när jag börjar arbeta igen efter en helgledighet

Reference: Gustafsson K, Lindfors P, Aronsson G; Lundberg U. (2008). Relationships between self-rating of recovery from work and morning salivary cortisol. J of Occup Health, 50(1), 24-30.

\section{Sleep quality}

Have you fallen asleep easily? (Haft svårt för att somna?)

100 Have you slept without waking up too early in the morning and not being able to fall asleep again? (Sovit utan att ha vaknat upp tidigt på morgonen utan att kunna somna om?)

101 How often have you felt well-rested when you woke up in the past week?

Reference: Partinen, M., \& Gislason, T. (1995). Basic Nordic Sleep Questionnaire (BNSQ): a quantitated measure of subjective sleep complaints. Journal of Sleep Research, 4 (Suppl. 1), 150-155.

\section{Sickness behavior} . sammanlagt varit borta från arbetet på grund av egen sjukdom (sjukskrivning, vård, behandling eller undersökning)?) dom de senaste tolv månaderna?) feeling that you really should have taken sick leave due to your state of health? (Har det under de senaste 12 månaderna hänt att Du gått till arbetet, trots att Du med tanke på Ditt hälsotillstånd, egentligen borde ha sjukskrivit dig?) 



\title{
11. Appendix C Swedish questionnaire
}

\author{
Medarbetarenkät om arbete och hälsa \\ Syftet med denna enkät âr att undersōka hur arbetsmiljön och arbetssituationen bidrar till medarbetarnas engagemang och \\ Syytet med denna enkät är att undersöka hur arbetsmiljön och arbetssituationen bidrar till medarbetarnas engagemang och hälsa \\ Enkäten är anonym och enskilda svar kan inte kopplas till individer. Din medverkan är frivillig men ju fler som deltar desto mer \\ ökar vår kunskap om hur vi kan skapa goda arbetsplatser där man trivs, mär och arbetar bra. Enkäten tar ca 20-30 minuter att \\ samrảd med lca Bankens HR-avdelning. \\ Forskningsprojektet är finansierat av Nordiska ministerrådet och vi som jobbar med projektet kommer från hela Norden \\ Är det nàgot du funderar över? \\ Kontakta Ulrika Lundberg: 070-6916489 e-post ulika.lundberg@neurophys.gu.se, eller \\ Gunnar Aronsson: 08-16 3960 e-post gunnar.aronsson@psychology.su.se \\ För tekniska frågor eller frågor angående datainsamlingen, kontakta Johan Guthenberg på e-post \\ johan guthenberg@psychology suse \\ Den här enkäten innehåller 40 frågor
}

\section{Bakgrundsfrågor}

1 Vilket år är du född? *

Skriv ditt svar här:

2 Kön? *

Vălj bara en av följande:

Kvinna

Man

3 Civilstånd *

Välj bara en av följande:

Ensamstảende

Gift/Sammanboende

Särbo

Kvarboende hos föräldrarna

4 Har du hemmavarande barn? *

Välj bara en av följande

O Ja 
$\mathrm{Nej}$

5 Vilken är den högsta utbildning du har genomgått? *

Välj bara en av följande:

Folk-, grund- eller realskola

Yrkesskola, särskild yrkesutbildning

Gymnasium eller motsvarande

Universitet/högskola

6 Hur många år har du arbetat för Ica Banken? *

Skriv dilt svar här:

(ning

7 På vilken avdelning arbetar du? *

Välj bara en av följande:

Privatmarknad

Utveckling \& förvaltning

Annat

8 Vilken typ av tjänst/anställningsform har du? *

Välj bara en av följande:

Tillsvidareanställning

Projektanställning (visstid)

Provanställning

9 Vad har du för befattning? *

Välj bara en av följande:

Chefstjänst med personalansvar

Chefstjänst utan personalansvar

Specialisttjänst

10 Vilka är dina arbetstider? *

Välj bara en av följande: 

Kontorstid med schema
Kontorstid utan schema
Beredskap
Både oct/blandat

11 Räknar du med att vara kvar på Ica Banken om fem år? * Vălj bara en av följande:

Ja, absolut

O Ja, sannolikt

Kanske

$\mathrm{Nej}$, troligtvis inte

Nej, absolut inte

12 Det yrke Du har idag - är det yrket du önskar ha i framtiden? * Vălj bara en av följande:

O Ja

$\mathrm{O} \mathrm{Nej}$

13 Den arbetsplats du har idag - är det den arbetsplats du önskar ha i framtiden? Vălj bara en av följande

Ja

$\mathrm{O} \mathrm{Nej}$

14 Känner du dig positiv inför hur ditt arbete kommer utvecklas i framtiden? * Vălj bara en av följande:

Inte alls

Nâgot positiv

Ganska positiv

Mycket positiv

Valdigt mycket positiv

15 Har du haft något utvecklingssamtal med din arbetsledare de senaste tolv månaderna?. *

Văli bara en av följande

$\mathrm{ONej}$

$\mathrm{Ja}$, en gâng

Ja, två gånger eller fler

16 Har du haft nytta av utvecklingssamtalen i ditt arbete? *

Svara bara pá denna frảga om följande villkor är uppfyllda: 'Svaret var 'Ja, en gång' eller 'Ja, två gånger eller fler' på fråga '15 [b15]' (Har du haft något utvecklingssamtal med din arbetsledare de senaste tolv mảnaderna?.)

Văli bara en av följande:

O Inte alls

Något

Ganska mycket

Mycket

Valdigt mycket 


\section{Krav i arbetet}

\begin{tabular}{|c|c|c|c|c|c|}
\hline \multicolumn{6}{|c|}{17 Om krav som ditt arbete ställer * } \\
\hline \multicolumn{6}{|c|}{ Välj det korrekta svaret för varje punkt: } \\
\hline & $\begin{array}{l}\text { Mycket } \\
\text { sällan eller } \\
\text { aldrig }\end{array}$ & $\begin{array}{l}\text { Ganska } \\
\text { sällan }\end{array}$ & $\begin{array}{l}\text { Ibland/dấ } \\
\text { och dâa }\end{array}$ & Ganska ofta & $\begin{array}{l}\text { Mycket ofta } \\
\text { eller alltid }\end{array}$ \\
\hline $\begin{array}{l}\text { Arbetar du i mycket } \\
\text { högt tempo? }\end{array}$ & 0 & 0 & 0 & 0 & 0 \\
\hline $\begin{array}{l}\text { Kräver ditt arbete } \\
\text { snabba beslut? }\end{array}$ & 0 & 0 & 0 & 0 & 0 \\
\hline $\begin{array}{l}\text { Är dina } \\
\text { arbetsuppgifter för } \\
\text { svâra för dig? }\end{array}$ & 0 & 0 & 0 & 0 & 0 \\
\hline $\begin{array}{l}\text { Kraver ditt arbete } \\
\text { maximal } \\
\text { uppmärksamnet? }\end{array}$ & 0 & 0 & 0 & 0 & 0 \\
\hline $\begin{array}{l}\text { Kräver ditt arbete } \\
\text { komplicerade beslut? }\end{array}$ & 0 & 0 & 0 & 0 & 0 \\
\hline $\begin{array}{l}\text { Utfor du } \\
\text { arbetsuppgifter som } \\
\text { du skulle behöva } \\
\text { mera utbildning for? }\end{array}$ & 0 & 0 & 0 & 0 & 0 \\
\hline $\begin{array}{l}\text { Är dina kunskaper } \\
\text { och färdigheter till } \\
\text { nytta i ditt arbete? }\end{array}$ & 0 & 0 & 0 & 0 & 0 \\
\hline $\begin{array}{l}\text { Tycker du att ditt } \\
\text { arbete är } \\
\text { meningsfullt? }\end{array}$ & 0 & 0 & 0 & 0 & 0 \\
\hline $\begin{array}{l}\text { Kräver ditt arbete att } \\
\text { du skaffar dig nya } \\
\text { kunskaper och } \\
\text { färdigheter? }\end{array}$ & 0 & 0 & 0 & 0 & 0 \\
\hline $\begin{array}{l}\text { Måste du utföra } \\
\text { saker som du tycker } \\
\text { skulle göras } \\
\text { annorlunda? }\end{array}$ & 0 & 0 & 0 & 0 & 0 \\
\hline $\begin{array}{l}\text { Får du } \\
\text { arbetsuppgifter utan } \\
\text { att få de resurser } \\
\text { som behövs för att } \\
\text { utföra dem? }\end{array}$ & 0 & 0 & 0 & 0 & 0 \\
\hline $\begin{array}{l}\text { Ställs det oförenliga } \\
\text { krav pá dig frân tvâ } \\
\text { eller flera personer? }\end{array}$ & 0 & 0 & 0 & 0 & 0 \\
\hline
\end{tabular}




\section{Engagemang}

18 Om engagemang... *

Valj det korrekta svaret fôr varje punkt:

\begin{tabular}{|c|c|c|c|c|c|c|c|}
\hline & Aldrig & $\begin{array}{l}\text { Några } \\
\text { ggr/âr } \\
\text { eller } \\
\text { mindre }\end{array}$ & $\begin{array}{l}\text { Nägon } \\
\text { ggr } \\
\text { mảnad } \\
\text { eller } \\
\text { mindre }\end{array}$ & $\begin{array}{c}\text { Nägra } \\
\text { ggr } \\
\text { mánaden }\end{array}$ & $\begin{array}{c}\text { Nägon } \\
\text { gâng/vecka }\end{array}$ & $\begin{array}{c}\text { Flera } \\
\text { ggr/veckan }\end{array}$ & $\begin{array}{l}\text { Varje } \\
\text { dag }\end{array}$ \\
\hline $\begin{array}{l}\text { Jag känner } \\
\text { mig stark och } \\
\text { energisk pá } \\
\text { jobbet }\end{array}$ & 0 & 0 & 0 & 0 & 0 & 0 & 0 \\
\hline $\begin{array}{l}\text { Jag känner } \\
\text { entusiasm } \\
\text { över mitt jobb }\end{array}$ & 0 & 0 & 0 & 0 & 0 & 0 & 0 \\
\hline $\begin{array}{l}\text { När jag jobbar } \\
\text { fokuserar jag } \\
\text { helt och hăller } \\
\text { pá uppgiften }\end{array}$ & 0 & 0 & 0 & 0 & 0 & 0 & 0 \\
\hline
\end{tabular}




\section{Återkoppling och uppskattning}

\begin{tabular}{|c|c|c|c|c|c|}
\hline \multicolumn{6}{|c|}{19 Om återkoppling av ditt arbete ... * } \\
\hline \multicolumn{6}{|c|}{ Valj det korrekta svaret för varje punkt: } \\
\hline & $\begin{array}{l}\text { Instämmer } \\
\text { inte alls }\end{array}$ & $\begin{array}{l}\text { Instämmer } \\
\text { lite }\end{array}$ & Varken eller & $\begin{array}{l}\text { Instämmer } \\
\text { nästan helt }\end{array}$ & $\begin{array}{l}\text { Instämmer } \\
\text { helt }\end{array}$ \\
\hline $\begin{array}{l}\text { I mitt arbete finns } \\
\text { mánga tillfällen att } \\
\text { bedöma hur väl jag } \\
\text { klarar arbetet }\end{array}$ & 0 & 0 & 0 & 0 & 0 \\
\hline $\begin{array}{l}\text { Mina chefer talar } \\
\text { ofta om för mig hur } \\
\text { de anser att jag } \\
\text { klarar mitt arbete }\end{array}$ & 0 & 0 & 0 & 0 & 0 \\
\hline $\begin{array}{l}\text { Det är latt för mig att } \\
\text { se mitt arbetes } \\
\text { positiva effekter }\end{array}$ & 0 & 0 & 0 & 0 & 0 \\
\hline \multicolumn{6}{|c|}{20 Om uppskattning för ditt arbete $\ldots *$ * } \\
\hline \multicolumn{6}{|c|}{ Välj det korrekta svaret för varje punkt: } \\
\hline & $\begin{array}{l}\text { Instämmer } \\
\text { inte alls }\end{array}$ & $\begin{array}{l}\text { Instämmer } \\
\text { lite }\end{array}$ & Varken eller & $\begin{array}{l}\text { Instämmer } \\
\text { nästan helt }\end{array}$ & $\begin{array}{l}\text { Instämmer } \\
\text { helt }\end{array}$ \\
\hline $\begin{array}{l}\text { Min arbetsledare } \\
\text { uppskattar mitt } \\
\text { arbete }\end{array}$ & 0 & 0 & 0 & 0 & 0 \\
\hline $\begin{array}{l}\text { Mitt arbete } \\
\text { uppskattas utanför } \\
\text { arbetsplatsen }\end{array}$ & 0 & 0 & 0 & 0 & 0 \\
\hline $\begin{array}{l}\text { Jag anser sjalv att } \\
\text { mitt arbete är viktigt }\end{array}$ & 0 & 0 & 0 & 0 & 0 \\
\hline
\end{tabular}




\section{Förtroende och rättvisa}

21 Om förtroende på din arbetsplats ... *

Valj det korrekta svaret fôr varje punkt:

\begin{tabular}{|c|c|c|c|c|c|}
\hline & $\begin{array}{l}\text { I mycket låg } \\
\text { grad }\end{array}$ & I lảg grad & Delvis & I hög grad & $\begin{array}{l}\text { I mycket } \\
\text { hög grad }\end{array}$ \\
\hline $\begin{array}{l}\text { Ledningen litar pả att } \\
\text { medarbetarna gör } \\
\text { ett bra arbete }\end{array}$ & 0 & 0 & 0 & 0 & 0 \\
\hline $\begin{array}{l}\text { Man kan lita pả den } \\
\text { information som } \\
\text { kommer frän } \\
\text { ledningen }\end{array}$ & 0 & 0 & 0 & 0 & 0 \\
\hline $\begin{array}{l}\text { Ledningen } \\
\text { undanhâller viktig } \\
\text { information frân } \\
\text { medarbetarna }\end{array}$ & 0 & 0 & 0 & 0 & 0 \\
\hline $\begin{array}{l}\text { De anstalllda kan fritt } \\
\text { uttrycka sin mening } \\
\text { och känsla (det är } \\
\text { "högt i tak" pá } \\
\text { arbetsplatsen) }\end{array}$ & 0 & 0 & 0 & 0 & 0 \\
\hline
\end{tabular}

\section{Om rättvisa på arbetsplatsen *}

Väjj det korrekta svaret för varje punkt

\begin{tabular}{|c|c|c|c|c|c|}
\hline & $\begin{array}{c}\text { I mycket låg } \\
\text { grad }\end{array}$ & I låg grad & Delvis & I hög grad & $\begin{array}{l}\text { I mycket } \\
\text { hög grad }\end{array}$ \\
\hline $\begin{array}{l}\text { Konflikter löses på } \\
\text { ett răttvist sătt }\end{array}$ & 0 & 0 & 0 & 0 & 0 \\
\hline $\begin{array}{l}\text { Anställda visas } \\
\text { uppskattning när de } \\
\text { gör ett bra arbete }\end{array}$ & 0 & 0 & 0 & 0 & 0 \\
\hline $\begin{array}{l}\text { Förslag från de } \\
\text { anställda tas seriöst } \\
\text { av ledningen }\end{array}$ & 0 & 0 & 0 & 0 & 0 \\
\hline $\begin{array}{l}\text { Arbetsuppgifter } \\
\text { fördelas răttvist }\end{array}$ & 0 & 0 & 0 & 0 & 0 \\
\hline
\end{tabular}


Samarbete och utvecklingsarbete

\begin{tabular}{|c|c|c|c|c|c|}
\hline \multicolumn{6}{|c|}{$23 \mathrm{Om}$ samarbete $\mathbf{i}$ arbetsgruppen ... * } \\
\hline \multicolumn{6}{|c|}{ Vallj det korrekta svaret för varje punkt: } \\
\hline & $\begin{array}{l}\text { Instämmer } \\
\text { inte alls }\end{array}$ & $\begin{array}{l}\text { Instämmer } \\
\text { lite }\end{array}$ & Varken eller & $\begin{array}{l}\text { Instämmer } \\
\text { nästan helt }\end{array}$ & $\begin{array}{l}\text { Instämmer } \\
\text { helt }\end{array}$ \\
\hline $\begin{array}{l}\text { Vår arbetsgrupp är } \\
\text { ense när det găller } \\
\text { satsningar för att nả } \\
\text { văra prestationsmál }\end{array}$ & 0 & 0 & 0 & 0 & 0 \\
\hline $\begin{array}{l}\text { Jag är nöjd med min } \\
\text { arbetsgrupps insats } \\
\text { för att nâ mâlen }\end{array}$ & 0 & 0 & 0 & 0 & 0 \\
\hline $\begin{array}{l}\text { Arbetsgruppens } \\
\text { medlemmar har } \\
\text { motstridiga } \\
\text { ambitioner gällande } \\
\text { văra prestationer }\end{array}$ & 0 & 0 & 0 & 0 & 0 \\
\hline $\begin{array}{l}\text { Jag har stora } \\
\text { möjligheter att } \\
\text { förbăttra mina } \\
\text { personliga } \\
\text { prestationer i den } \\
\text { här arbetsgruppen }\end{array}$ & 0 & 0 & 0 & 0 & 0 \\
\hline \multicolumn{6}{|c|}{24 Om utvecklingsarbete ... * } \\
\hline \multicolumn{6}{|c|}{ Välj det korrekta svaret för varje punkt: } \\
\hline & $\begin{array}{l}\text { Nastan } \\
\text { aldrig }\end{array}$ & $\begin{array}{l}\text { Ganska } \\
\text { săllan }\end{array}$ & Dả och dả & Ganska ofta & Mycket ofta \\
\hline $\begin{array}{l}\text { Det görs ständigt } \\
\text { förbättringar i } \\
\text { verksamheten }\end{array}$ & 0 & 0 & 0 & 0 & 0 \\
\hline $\begin{array}{l}\text { Pâ min arbetsplats } \\
\text { diskuterar vi } \\
\text { tillsammans } \\
\text { arbetsuppgifter, } \\
\text { mälsăttningar och } \\
\text { sätt att uppnå målen }\end{array}$ & 0 & 0 & 0 & 0 & 0 \\
\hline $\begin{array}{l}\text { Vi skaffar oss } \\
\text { feedback och } \\
\text { förbabttringsidéer från } \\
\text { văra kunder }\end{array}$ & 0 & 0 & 0 & 0 & 0 \\
\hline
\end{tabular}




\section{Respekt och meningsfullhet}

25 Om respekt på din arbetsplats ... *

Văjj det korrekta svaret fôr varje punkt:

$\begin{array}{lccccc} & \begin{array}{c}\text { I mycket låg } \\ \text { grad }\end{array} & \text { I låg grad } & \text { Delvis } & \text { I hög grad } & \begin{array}{c}\text { I mycket } \\ \text { hög grad }\end{array} \\ \begin{array}{l}\text { Det är god stämning } \\ \text { mellan mig och mina } \\ \text { kollegor }\end{array} & 0 & 0 & 0 & 0 & 0 \\ \begin{array}{l}\text { Det ăr gott } \\ \text { samarbete på min } \\ \text { arbetsplats }\end{array} & 0 & 0 & 0 & 0 & 0 \\ \begin{array}{l}\text { Jag kănner att jag âr } \\ \text { en del av gruppen pá } \\ \text { min arbetsplats }\end{array} & 0 & 0 & 0 & 0 & 0\end{array}$

26 Om arbetets meningsfullhet ... *

Vălj det korrekta svaret för varje punkt:

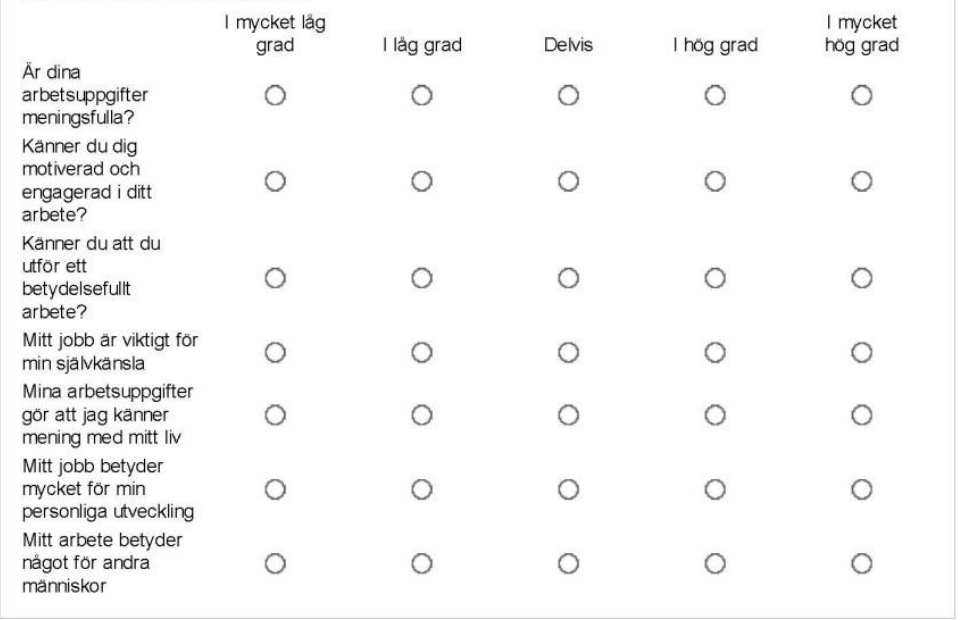




\section{Balans mellan arbete och privatliv}

27 Hur betydelsefullt är arbetet i ditt liv? *

Välj bara en av följande:

Inte alls viktigt

Ganska oviktigt

Ganska viktigt

Det viktigaste i mitt liv

28 Om balans mellan ditt arbete och privatlivet ... *

Välj det korrekta svaret för varje punkt:

$\begin{aligned} & \text { Påverkar kraven i ditt } \\ & \text { arbete ditt hem och } \\ & \text { familjeliv pá ett } \\ & \text { negativt sătt? }\end{aligned}$
$\begin{aligned} & \text { Päverkar kraven i ditt } \\ & \text { hem/din familj ditt } \\ & \text { arbete pá ett } \\ & \text { negativt sătt? }\end{aligned}$

\begin{tabular}{|lll|l} 
Aldrig Sallan Ibland & $\begin{array}{c}\text { Enstor del } \\
\text { avtiden }\end{array}$ Hela tiden \\
arbetsdag &
\end{tabular}




\section{Lojalitet}

29 Om din lojalitet till organisationen och arbetsgivaren ... *

Välj det korrekta svaret för varje punkt:

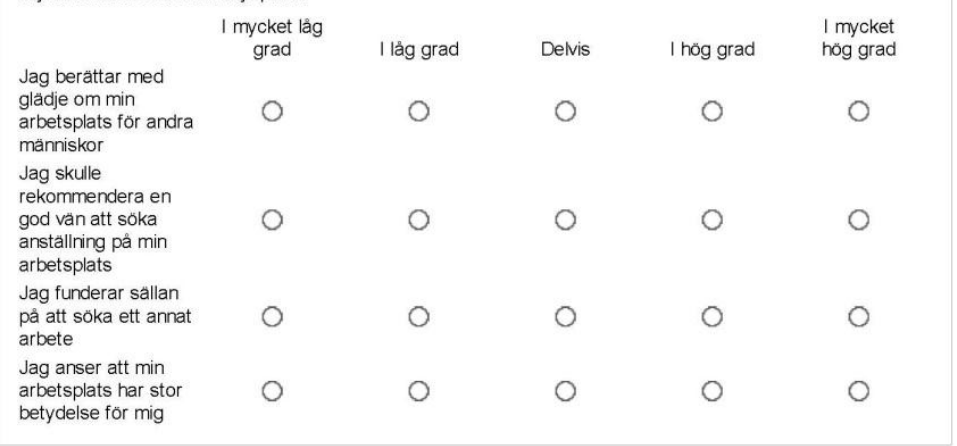




\section{Personligt förhållningssätt}

30 Om ditt personliga förhållningssätt ... *

Välj det korrekta svaret för varje punkt:

När något går fel Instämmer
inte alls Instämmer Varkener Instämmer Instämmer söker jag genast en lite Varken eller

Om det bara ar

möjligt vill jag aktivt

vara med

Jag tar genast

initiativet också năr

andra inte gör det

I allmänhet gör jag

mer än vad som

Jag niuter av att
hálla pá med

problem som är helt

nya för mig

Jag niuter av att

försokka losa

komplicerade

problem
Jag vill att mitt

arbete skall ge mig

mojligheter att öka

mina kunskaper och

färdigheter

Nyfikenhet är

drivkraften bakom

mycket jag gör

När jag deltar i en

aktivitet har jag en

endens till att bli sá

involverad att jag

Närr jag är irtensivt

skall det mycket till

för att fả stopp pá

fơr att fá stopp pá

mig

Mina vänner skulle

beskriva mig som

"extremt intensiv" na

jag âr mitt uppe i

nágot

Jag tror att konst

kan betyda mycket

Jag alskar att

komma pá nya sătt

att göra saker på

Jag tycker om att

0

0

0

O

0

Jag tycker om att
höra om nya idéer

$0 \quad 0$

O 0

0

0

O

\begin{tabular}{|lccccc|}
\hline $\begin{array}{l}\text { Instämmer } \\
\text { inte alls }\end{array}$ & $\begin{array}{c}\text { Instämmer } \\
\text { lite }\end{array}$ & Varken eller & $\begin{array}{c}\text { Instämmer } \\
\text { nästan helt }\end{array}$ & $\begin{array}{c}\text { Instämmer } \\
\text { helt }\end{array}$ \\
$\begin{array}{l}\text { Jag kan få ett samtal } \\
\text { nivăta till en högre }\end{array}$ & 0 & 0 & 0 & 0 & 0 \\
$\begin{array}{l}\text { Jag föredrar } \\
\text { variation framför rutin } \\
\text { Jag tycker om att }\end{array}$ & 0 & 0 & 0 & 0 & 0 \\
$\begin{array}{l}\text { losa komplicerade } \\
\text { problem }\end{array}$ & 0 & 0 & 0 & 0 & 0 \\
\hline
\end{tabular}




\section{Återhämtning och avkoppling}

33 Om återhämtning och avkoppling ... *

Välj det korrekta svaret fôr varje punkt

\begin{tabular}{|c|c|c|c|c|c|}
\hline & Aldrig & Sallan & Ibland & Ganska ofta & Mycket ofta \\
\hline $\begin{array}{l}\text { Jag känner mig } \\
\text { utvilad och } \\
\text { âterhämtad när jag } \\
\text { börjar arbetet pá } \\
\text { morgonen }\end{array}$ & 0 & 0 & 0 & 0 & 0 \\
\hline $\begin{array}{l}\text { Jag känner mig fylld } \\
\text { av energi under } \\
\text { arbetsdagen }\end{array}$ & 0 & 0 & 0 & 0 & 0 \\
\hline $\begin{array}{l}\text { Jag känner mig } \\
\text { mycket trött under } \\
\text { arbetsdagen }\end{array}$ & 0 & 0 & 0 & 0 & 0 \\
\hline $\begin{array}{l}\text { Jag känner du mig } \\
\text { utvilad och } \\
\text { aterhämtad när jag } \\
\text { borjar arbeta igen } \\
\text { efter en helgledighet }\end{array}$ & 0 & 0 & 0 & 0 & 0 \\
\hline
\end{tabular}




\section{Sjukskrivning och sömn}

34 Hur Hur många gånger under de senaste 12 månaderna har du sammanlagt varit borta från arbetet på grund av egen sjukdom (sjukskrivning, vård, behandling eller undersökning)? *
Välj bara en av följande:
Aldrig
En gång
$2-5 \mathrm{ggr}$
$>>5$ ggr

35 Hur många dagar - ungefär - har du varit frånvarande p.g.a. sjukdom de senaste tolv månaderna? *

Skriv ditt svar hăr

36 Har det under de senaste 12 månaderna hänt att Du gått till arbetet, trots att Du med tanke på Ditt hälsotillstånd, egentligen borde ha sjukskrivit dig? *

Vălj bara en av följande:

Aldrig

En gâng

$2-5$ ggr

$>5 \mathrm{ggr}$

Ej aktuellt/ej varit sjuk

37 Har du under de tre senaste månaderna ... *

Välj det korrekta svaret för varje punkt:

$\begin{array}{lccccc} & \begin{array}{c}\text { Aldrig, el. < } \\ \text { en gång i } \\ \text { mánaden }\end{array} & \begin{array}{c}\text { Mer săllan } \\ \text { än en dag i } \\ \text { veckan }\end{array} & \begin{array}{c}1-2 \text { nătter i } \\ \text { veckan }\end{array} & \begin{array}{c}3-5 \text { nătter i } \\ \text { veckan }\end{array} & \begin{array}{c}\text { Dagligen el. } \\ \text { nästan } \\ \text { dagligen }\end{array} \\ \begin{array}{l}\text { Haft svårt för att } \\ \text { somna? }\end{array} & 0 & 0 & 0 & 0 & 0 \\ \begin{array}{l}\text { Sovit bra hela } \\ \text { natten? }\end{array} & 0 & 0 & 0 & 0 & 0 \\ \begin{array}{l}\text { Sovit utan att ha } \\ \text { vaknat upp tidigt på } \\ \text { morgonen utan att } \\ \text { kunna somna om? }\end{array} & 0 & 0 & 0 & 0 & 0\end{array}$

38 Hur ofta har du känt dig utsövd när du vaknat under den senaste veckan? *

Välj bara en av följande:
Ingen morgon
Ett par morgnar
De flesta morgnar
Alla morgnar 


\section{Prestation}

39 Om prestation ... *

Valj det korrekta svaret fôr varje punkt:

\begin{tabular}{|c|c|c|c|c|c|}
\hline & $\begin{array}{l}\text { Aldrig/nästan } \\
\quad \text { aldrig }\end{array}$ & Sällan & Ibland & Ofta & $\begin{array}{c}\text { Nästan } \\
\text { alltid/alltid }\end{array}$ \\
\hline $\begin{array}{l}\text { Jag har kompetens } \\
\text { inom alla } \\
\text { delomráden i mitt } \\
\text { arbete }\end{array}$ & 0 & 0 & 0 & 0 & 0 \\
\hline $\begin{array}{l}\text { Jag är kompetent } \\
\text { inom alla arbetets } \\
\text { olika delområden, } \\
\text { och jag sköter mina } \\
\text { uppgifter med } \\
\text { yrkesskicklighet }\end{array}$ & 0 & 0 & 0 & 0 & 0 \\
\hline $\begin{array}{l}\text { Jag klarar av mitt } \\
\text { arbete väl i dess } \\
\text { helhet, genom att } \\
\text { utföra arbetet sâ } \\
\text { som det skall göras }\end{array}$ & 0 & 0 & 0 & 0 & 0 \\
\hline $\begin{array}{l}\text { Jag gör frivilligt } \\
\text { sádant som inte } \\
\text { formellt krävs i mitt } \\
\text { arbete }\end{array}$ & 0 & 0 & 0 & 0 & 0 \\
\hline $\begin{array}{l}\text { Jag föreslår } \\
\text { ấgärder för att } \\
\text { fôrbättra kvaliteten } \\
\text { på verksamheten på } \\
\text { văr arbetsplats }\end{array}$ & 0 & 0 & 0 & 0 & 0 \\
\hline $\begin{array}{l}\text { Jag hiallper andra } \\
\text { om deras } \\
\text { arbetsbörda ökar, } \\
\text { tills de kommit over } \\
\text { det vărsta }\end{array}$ & 0 & 0 & 0 & 0 & 0 \\
\hline $\begin{array}{l}\text { Jag hialper mina } \\
\text { arbetskamrater med } \\
\text { deras uppgifter }\end{array}$ & 0 & 0 & 0 & 0 & 0 \\
\hline
\end{tabular}




\section{Synpunkter}

40 Om du har några synpunkter på undersökningen får du gärna lämna dessa här.

Skriv ditt svar hår:

PsySurvey - Medarbetarenkat on arbete och hâlsa

Stort tack for din medverkan

04.03.2011-19.32

Skicka in din enkät.

Tack för att du suarat pà denna enkät. https:/survey psychology su se/limesurvey/admin/admin php?action=s...

$2011-03-042008$ 


\section{Appendix D Norwegian questionnaire}

Medarbeiderundersøkelse om arbeid og helse

\begin{tabular}{|c|}
\hline $\begin{array}{l}\text { INVITASJON TIL DELTAGELSE I PROSJEKTET: } \\
\text { ENGASJEMENT OG SUNNE ORGANISASJONER }\end{array}$ \\
\hline $\begin{array}{l}\text { Dette er en invitasjon til a delta i en sperreskjemaundersokelse knyttet til prosjektet } \\
\text { "Engasjement og sunne organisajjoner?" }\end{array}$ \\
\hline 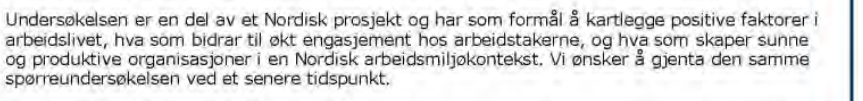 \\
\hline 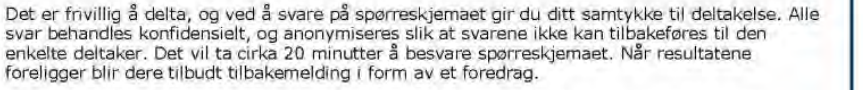 \\
\hline $\begin{array}{l}\text { NTNU ved Marit Christensen og Lisa Vivoll Straume er ansvarlige for denne undersokelsen. } \\
\text { Datamateraibet vil bli brukt av det Nordiske forskningsprosjektet, samt av fire } \\
\text { mastergradsstudenter ved master i helse-, organisasjon- og kommunikasjonspsykologi. }\end{array}$ \\
\hline 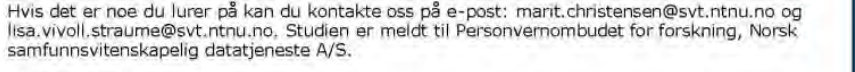 \\
\hline Med vennlig hilsen \\
\hline $\begin{array}{l}\text { Marit Christensen } \\
\text { Tlf. } 73591976\end{array}$ \\
\hline $\begin{array}{l}\text { Lisa Vivoll Straume } \\
\text { TIf. } 99620212\end{array}$ \\
\hline
\end{tabular}

目

Medarbeiderundersøkelse om arbeid og helse

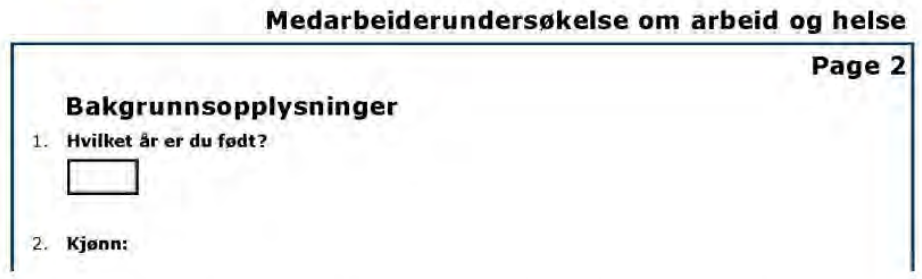




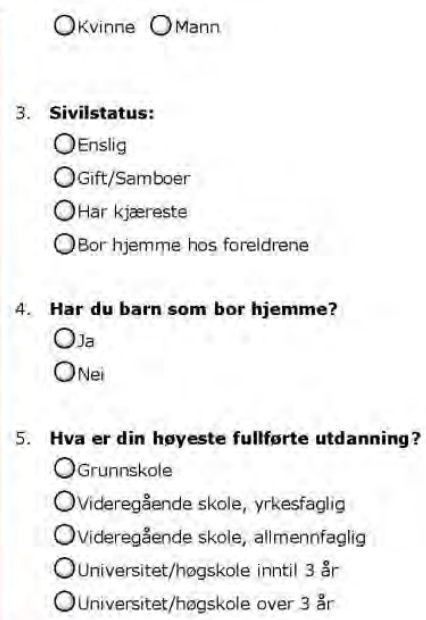

Medarbeiderundersøkelse om arbeid og helse

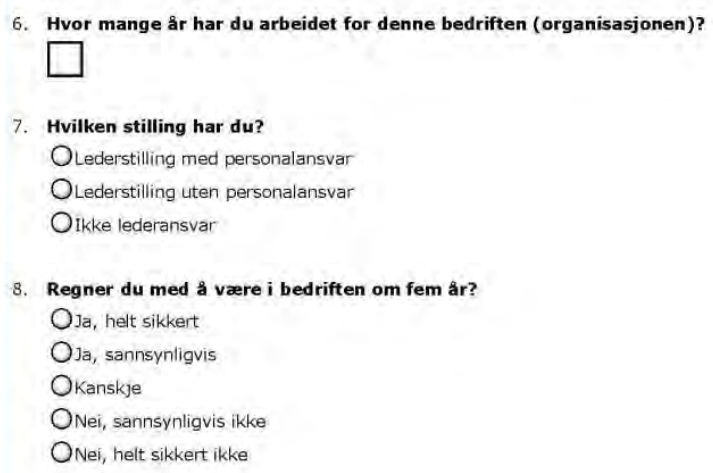


9. Det yrket du har i dag - er det yrket du ønsker å ha i framtiden ?

Oja

ONei

10. Den arbeidsplassen du har idag - er det den arbeidsplassen du ønsker å ha î framtiden?

Oja

$\mathrm{ONei}$

11. Er du positiv til hvordan jobben din vil utvikle seg i fremtiden?

OIkke i det hele tatt

Olitt positiv

OGanske positiv

Oveldig positiv

Osvært positiv

12. Har du hatt dialogsamtale med din arbeidsleder de siste 12 mânedene?

ONet

Ja, en gang

Ola, to ganger eller fler

[]

Medarbeiderundersøkelse om arbeid og helse

\begin{tabular}{|l|}
\multicolumn{1}{l}{ Medarbeiderundersøkelse om arbeid og helse } \\
Medarbeidersamtalen \\
Page 4 \\
13. Har du hatt nytte av dialogsamtalen i arbeidet ditt? \\
Orkke i det hele tatt \\
Onoe \\
OGanske mye \\
OMye \\
Oveldig mye
\end{tabular}

file://CI/.../AppData/Local/Microsoft/Windows/Temporary Internet Files/Content.Outlook/QGZM3EST/Webspørreskema (3).htm[18.04.2012 11:58:09] 
[]

Medarbeiderundersøkelse om arbeid og helse

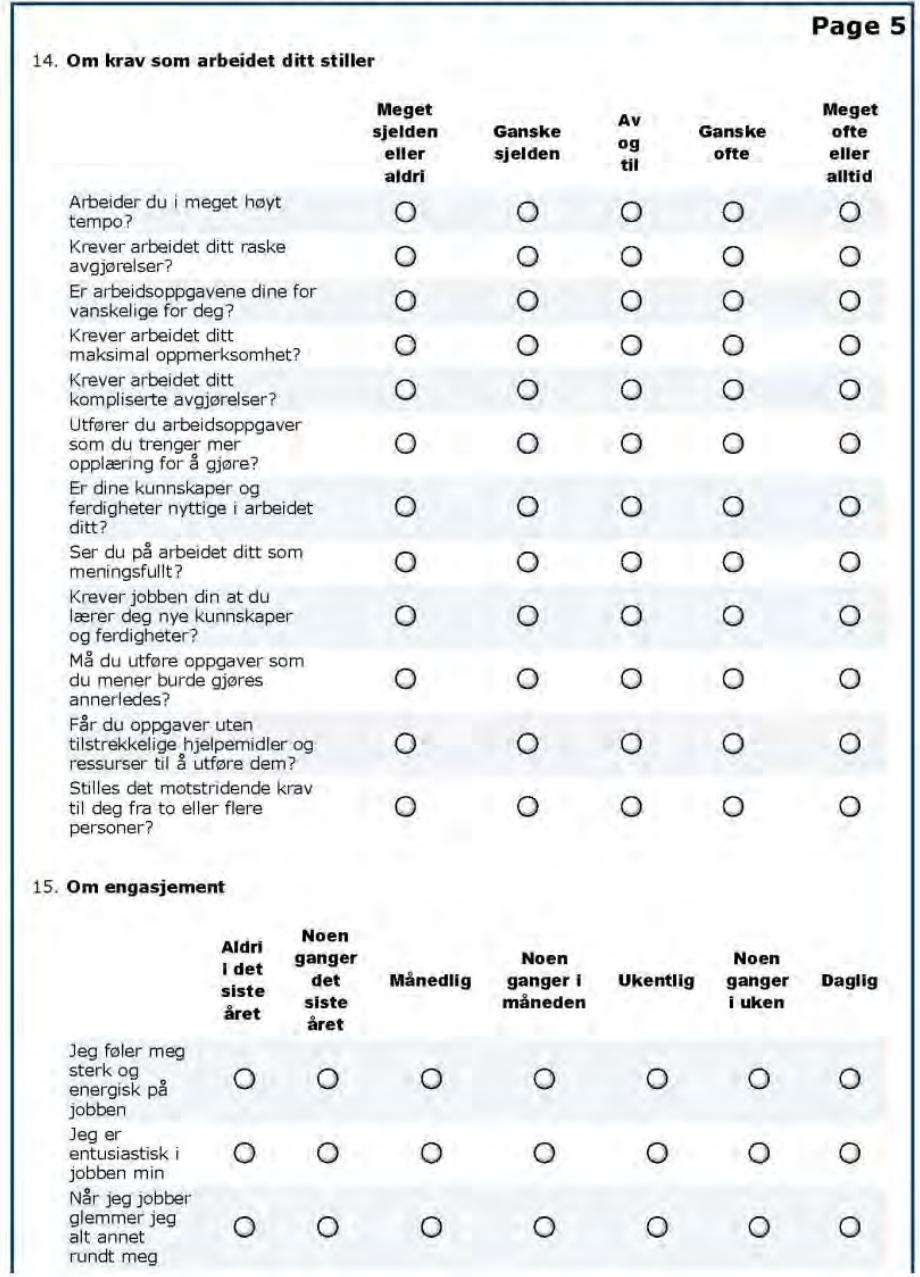

file:///C|/.../AppData/Loca//Microsoft/Windows/Temporary Internet Files/Content.Outlook/QGZM3EST/Webspørreskjema (3).htm[18.04.2012 11:58:09] 


\begin{tabular}{|c|c|c|c|c|c|}
\hline \multicolumn{6}{|c|}{ 16. Om tilbakemelding på arbeidet ditt } \\
\hline & $\begin{array}{l}\text { Svært } \\
\text { uenig }\end{array}$ & Uenig & $\begin{array}{l}\text { Verken } \\
\text { eller }\end{array}$ & Enig & $\begin{array}{l}\text { Svart } \\
\text { enig }\end{array}$ \\
\hline 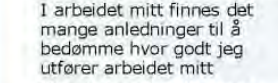 & 0 & 0 & 0 & 0 & 0 \\
\hline $\begin{array}{l}\text { Mine ledere forteller meg } \\
\text { offe hvordana de vurderer } \\
\text { min jobbutforelse }\end{array}$ & 0 & 0 & 0 & 0 & 0 \\
\hline $\begin{array}{l}\text { Det er lett for meg å se de } \\
\text { positive effektene av } \\
\text { arbeidet mitt }\end{array}$ & 0 & 0 & 0 & 0 & 0 \\
\hline \multicolumn{6}{|c|}{ 17. Om anerkjennelse av arbeidet ditt } \\
\hline & $\begin{array}{l}\text { Svært } \\
\text { uenig }\end{array}$ & Uenig & $\begin{array}{l}\text { Verken } \\
\text { eller }\end{array}$ & Enig & $\begin{array}{l}\text { Svært } \\
\text { enig }\end{array}$ \\
\hline $\begin{array}{l}\text { Mine ledere verdsetter } \\
\text { arbeidet mitt }\end{array}$ & 0 & 0 & 0 & 0 & 0 \\
\hline $\begin{array}{l}\text { Mitt arbeid verdsettes } \\
\text { utenfor arbeidsplassen }\end{array}$ & 0 & 0 & 0 & 0 & 0 \\
\hline $\begin{array}{l}\text { Jeg anser milt arbeid som } \\
\text { viktig }\end{array}$ & 0 & 0 & 0 & 0 & 0 \\
\hline
\end{tabular}

[]

Medarbeiderundersøkelse om arbeid og helse

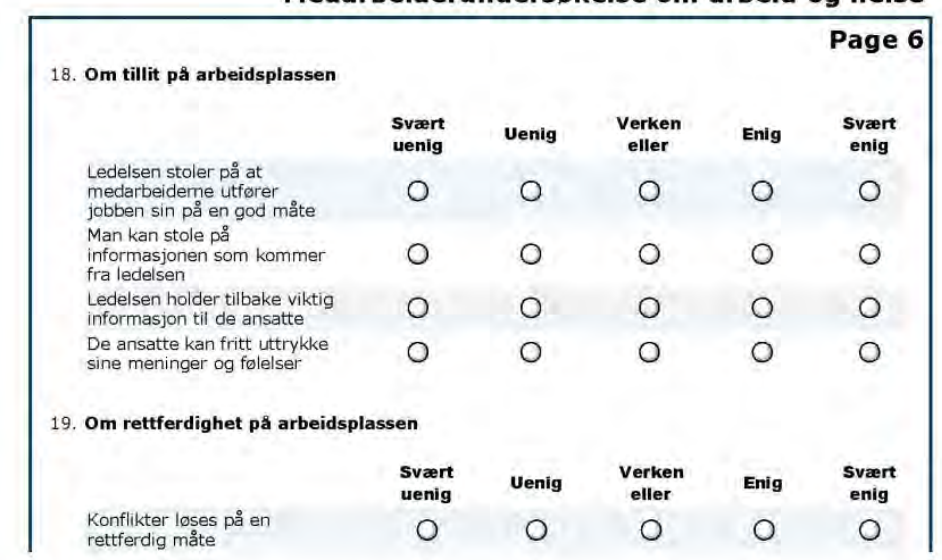

file:///CI/.../AppData/Local/Microsoft/Windows/Temporary Internet Files/Content.Outlook/QGZM3EsT/Webspørreskjema (3).htm[18.04.2012 11:58:09] 


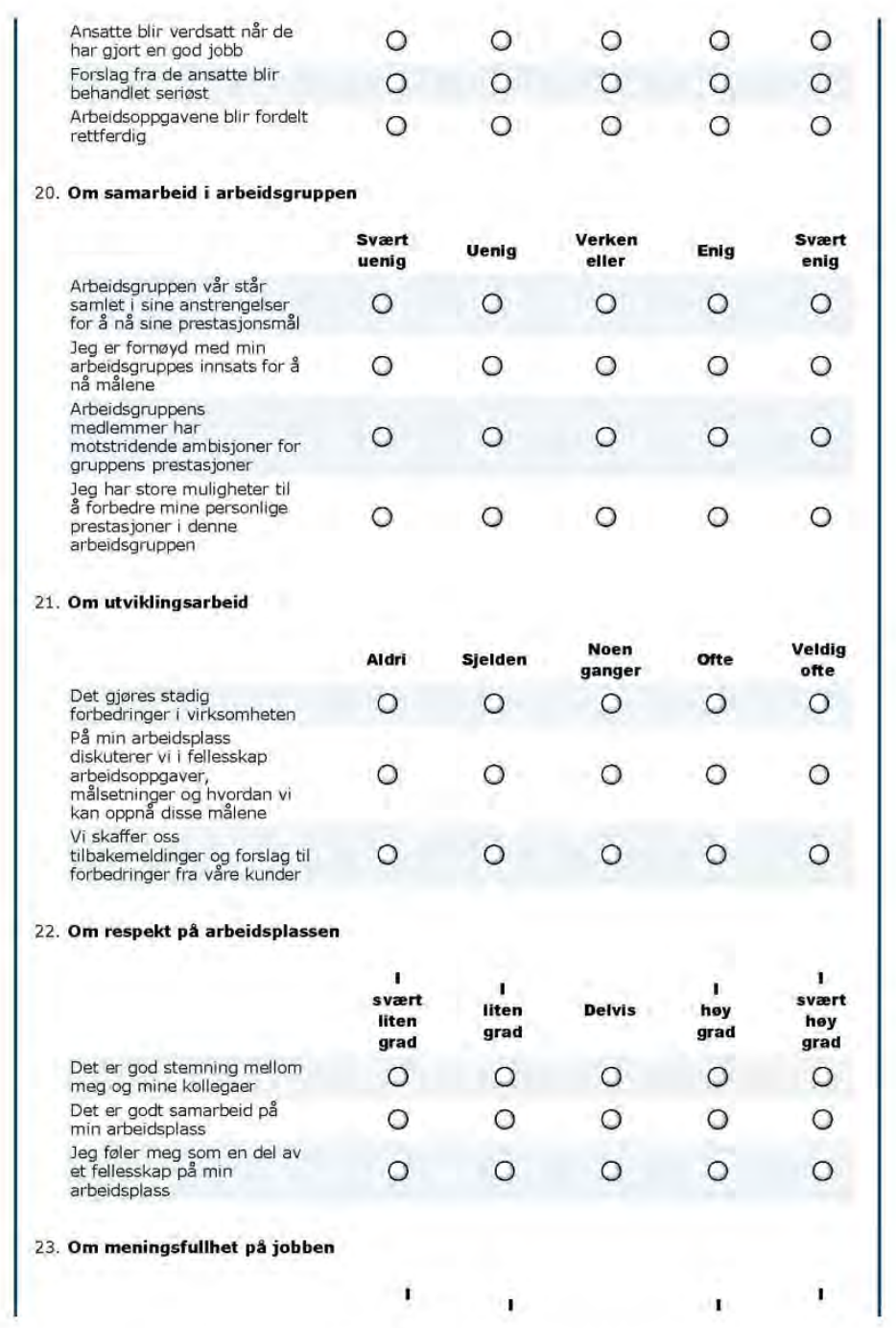

file:///CI/.../AppData/Local/Microsoft/Windows/Temporary Internet Files/Content.Outlook/QGZM3EsT/Webspørreskjema (3).htm[18.04.2012 11:58:09] 


\begin{tabular}{|c|c|c|c|c|c|}
\hline & $\begin{array}{l}\text { svært } \\
\text { liten } \\
\text { grad }\end{array}$ & $\begin{array}{l}\text { liten } \\
\text { grad }\end{array}$ & Delvis & $\begin{array}{l}\text { hoy } \\
\text { grad }\end{array}$ & $\begin{array}{c}\text { svært } \\
\text { hey } \\
\text { grad }\end{array}$ \\
\hline $\begin{array}{l}\text { Er dine arbeidsoppgaver } \\
\text { meningsfulle? }\end{array}$ & 0 & 0 & 0 & 0 & 0 \\
\hline $\begin{array}{l}\text { Foler du deg motivert og } \\
\text { engasjert i ditt arbeid? }\end{array}$ & 0 & 0 & 0 & 0 & 0 \\
\hline $\begin{array}{l}\text { Foler du at du gjør en viktig } \\
\text { jobb? }\end{array}$ & 0 & 0 & 0 & 0 & 0 \\
\hline $\begin{array}{l}\text { Min jobb er viktig for min } \\
\text { selvitlilit }\end{array}$ & O & 0 & 0 & 0 & 0 \\
\hline $\begin{array}{l}\text { Mine arbeidsoppgaver gjor at } \\
\text { jeg foler at livet mitt er } \\
\text { meningsfullt }\end{array}$ & 0 & 0 & 0 & 0 & 0 \\
\hline $\begin{array}{l}\text { Min jobb betyr mye for min } \\
\text { personlige utvikling }\end{array}$ & 0 & 0 & 0 & 0 & 0 \\
\hline $\begin{array}{l}\text { Mitt arbeid betyr noe for andre } \\
\text { mennesker }\end{array}$ & 0 & 0 & 0 & 0 & 0 \\
\hline
\end{tabular}

回

Medarbeiderundersøkelse om arbeid og helse

\begin{tabular}{|c|c|c|c|c|c|}
\hline & & & & & Page 7 \\
\hline \multicolumn{6}{|c|}{ 24. Hvor betydningsfulit er arbeidet $i$ ditt liv? } \\
\hline \multicolumn{6}{|l|}{ OIkke viktig i det hele tatt } \\
\hline \multicolumn{6}{|l|}{ OGanske uviktig } \\
\hline \multicolumn{6}{|l|}{ OGanske viktig } \\
\hline \multicolumn{6}{|l|}{ ODet viktigste i livet mitt } \\
\hline \multicolumn{6}{|c|}{ 25. Om balanse mellom ditt arbeid og privatliv } \\
\hline & Aldri & Sjelden & $\begin{array}{l}\text { Av } \\
\text { og } \\
\text { til }\end{array}$ & $\begin{array}{l}\text { En } \\
\text { stor } \\
\text { del } \\
\text { av } \\
\text { tiden }\end{array}$ & $\begin{array}{c}\text { Hele } \\
\text { tiden }\end{array}$ \\
\hline $\begin{array}{l}\text { Påvirirker kravene i arbeidet } \\
\text { hjemme- og familielivet ditt på } \\
\text { en negativ măte? }\end{array}$ & 0 & O & 0 & 0 & 0 \\
\hline $\begin{array}{l}\text { Har kravene fra } \\
\text { hjemmet/familien en negativ } \\
\text { effekt pă ditt arbeid? }\end{array}$ & O & 0 & 0 & 0 & 0 \\
\hline $\begin{array}{l}\text { Det jeg gjor i mitt arbeid drar } \\
\text { jeg nytte av når jeg hăndterer } \\
\text { menneskelige relasjoner og } \\
\text { praktiske saker i hjemmet }\end{array}$ & 0 & 0 & 0 & 0 & 0 \\
\hline $\begin{array}{l}\text { Det jeg gjør I mitt arbeid gjør } \\
\text { meg ogsa til en mer } \\
\text { interessant person hjemme }\end{array}$ & 0 & 0 & 0 & 0 & 0 \\
\hline $\begin{array}{l}\text { Ferdighetene jeg anvender i } \\
\text { mitt arbeid er også til nytte }\end{array}$ & & & & & \\
\hline
\end{tabular}

file:///CI/.../AppData/Local/Microsoft/Windows/Temporary Internet Files/Content.Outlook/QGZM3EST/Webspørreskjema (3).htm[18.04.2012 11:58:09] 


\begin{tabular}{|c|c|c|c|c|c|}
\hline $\begin{array}{l}\text { năr jeg håndterer utfordringer } \\
\text { pă hjemmebane }\end{array}$ & 0 & 0 & 0 & 0 & 0 \\
\hline $\begin{array}{l}\text { Arbeidsrelaterte problemer } \\
\text { virker lettere å handtere når } \\
\text { jeg har noen à snakke med } \\
\text { hjemme }\end{array}$ & 0 & 0 & 0 & 0 & 0 \\
\hline $\begin{array}{l}\text { Kjerrlighet og respekt fra min } \\
\text { familie styrker min selvtillit på } \\
\text { jobb }\end{array}$ & 0 & 0 & 0 & 0 & 0 \\
\hline $\begin{array}{l}\text { Mitt hjem/min familie hjelper } \\
\text { meg med a s laappe av og } \\
\text { forberede meg til neste } \\
\text { arbeidsdag }\end{array}$ & 0 & 0 & 0 & 0 & 0 \\
\hline \multicolumn{6}{|c|}{ 26. Om din lojalitet til organisasjonen og arbeidsgiveren } \\
\hline & $\begin{array}{l}1 \\
\text { svært } \\
\text { liten } \\
\text { grad }\end{array}$ & $\begin{array}{l}\text { ' } \\
\text { liten } \\
\text { grad }\end{array}$ & Delvis & $\begin{array}{c}\text { ' } \\
\text { hoy } \\
\text { grad }\end{array}$ & $\begin{array}{c}\text { ' } \\
\text { svært } \\
\text { hey } \\
\text { grad }\end{array}$ \\
\hline $\begin{array}{l}\text { Jeg liker a forteile om min } \\
\text { arbeidsplass til andre } \\
\text { mennesker }\end{array}$ & 0 & 0 & 0 & 0 & 0 \\
\hline $\begin{array}{l}\text { Jeg ville anbefalt en god } \\
\text { venn til à soke jobb på min } \\
\text { arbeidsplass }\end{array}$ & 0 & 0 & 0 & 0 & 0 \\
\hline $\begin{array}{l}\text { Jeg tenker sjelden på å soke } \\
\text { etter en annen jobb }\end{array}$ & 0 & 0 & 0 & 0 & 0 \\
\hline $\begin{array}{l}\text { Jeg anser at min } \\
\text { arbeidsplass har stor } \\
\text { betydning for meg }\end{array}$ & 0 & 0 & 0 & 0 & 0 \\
\hline
\end{tabular}

[

Medarbeiderundersøkelse om arbeid og helse

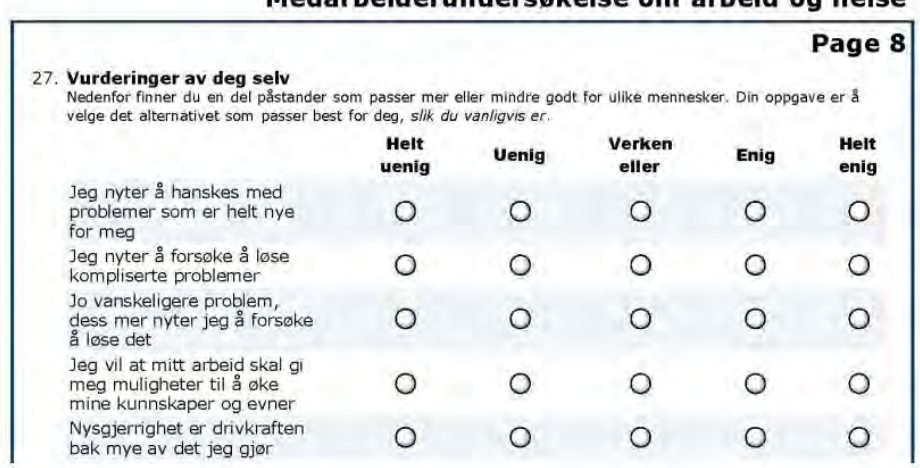

file:///CI/.../AppData/Local/Microsoft/Windows/Temporary Internet Files/Content.Outlook/QGZM3EsT/Webspørreskjema (3).htm[18.04.2012 11:58:09] 


\begin{tabular}{|c|c|c|c|c|c|c|c|}
\hline \multicolumn{2}{|c|}{$\begin{array}{l}\text { Når jeg deltar i en aktivitet } \\
\text { har jeg en tendens tili à bli så } \\
\text { involvert at jeg "glemmer } \\
\text { tiden" }\end{array}$} & 0 & 0 & 0 & & 0 & 0 \\
\hline \multicolumn{2}{|c|}{$\begin{array}{l}\text { Når jeg er intenst interessert } \\
\text { anoe, skal det mye til for ă } \\
\text { avbryte meg }\end{array}$} & 0 & 0 & 0 & & 0 & 0 \\
\hline \multirow{2}{*}{\multicolumn{2}{|c|}{$\begin{array}{l}\text { Mine venner vil beskrive meg } \\
\text { som "ekstremt intens" nar } \\
\text { jeg er midt oppe i noe } \\
\text { Jeg tror på betydningen av } \\
\text { kunst }\end{array}$}} & 0 & 0 & 0 & & 0 & 0 \\
\hline & & 0 & 0 & 0 & & 0 & 0 \\
\hline \multicolumn{2}{|c|}{$\begin{array}{l}\text { Jeg elsker å komme på nye } \\
\text { matter à gjore ting pă }\end{array}$} & 0 & 0 & 0 & & 0 & 0 \\
\hline \multicolumn{2}{|c|}{ Jeg liker ă hore om nye ideer } & 0 & 0 & 0 & & 0 & 0 \\
\hline \multicolumn{2}{|c|}{$\begin{array}{l}\text { Jeg kan lofte samtalen til et } \\
\text { hoyeré nivă }\end{array}$} & 0 & 0 & 0 & & 0 & 0 \\
\hline \multicolumn{2}{|c|}{$\begin{array}{l}\text { Jeg foretrekker variasjon } \\
\text { fremfor rutine }\end{array}$} & 0 & 0 & 0 & & 0 & 0 \\
\hline \multicolumn{2}{|c|}{$\begin{array}{l}\text { Jeg liker å Iose kompliserte } \\
\text { problemer }\end{array}$} & 0 & 0 & 0 & & 0 & 0 \\
\hline \multicolumn{2}{|c|}{$\begin{array}{l}\text { Jeg mestrer de fleste } \\
\text { oppgaver }\end{array}$} & 0 & 0 & 0 & & 0 & 0 \\
\hline \multirow{2}{*}{\multicolumn{2}{|c|}{$\begin{array}{l}\text { Jeg kan utfore en rekke ulike } \\
\text { oppgaver } \\
\text { Jeg moter gjerne utfordrende } \\
\text { oppgaver }\end{array}$}} & 0 & 0 & 0 & & 0 & 0 \\
\hline & & 0 & 0 & 0 & & 0 & 0 \\
\hline \multicolumn{2}{|c|}{$\begin{array}{l}\text { Jeg vet hvordan jeg skal } \\
\text { anvende mine kunnskaper }\end{array}$} & 0 & 0 & 0 & & 0 & 0 \\
\hline \multicolumn{8}{|l|}{ 3. Om optimisme } \\
\hline & & $\begin{array}{c}\text { Helt } \\
\text { uenig }\end{array}$ & Uenig & Både/o & & Enig & $\begin{array}{l}\text { Helt } \\
\text { enig }\end{array}$ \\
\hline \multirow{2}{*}{\multicolumn{2}{|c|}{$\begin{array}{l}\text { I usikre tider forventer } \\
\text { jeg som regel det beste } \\
\text { Jeg er alltid odtimistisk } \\
\text { med tanke pă fremtiden } \\
\text { min }\end{array}$}} & 0 & 0 & 0 & & 0 & 0 \\
\hline & & 0 & 0 & 0 & & 0 & 0 \\
\hline \multicolumn{2}{|c|}{$\begin{array}{l}\text { Alt } \mathrm{i} \text { alt forventer jeg at } \\
\text { flere gode enn darlige } \\
\text { ting skjer med meg }\end{array}$} & 0 & 0 & 0 & & 0 & 0 \\
\hline \multicolumn{8}{|c|}{ Om tilfredshet med livet generelt } \\
\hline & $\begin{array}{c}\text { Helt } \\
\text { uenig }\end{array}$ & Uenig & $\begin{array}{l}\text { Deelvis } \\
\text { uenig }\end{array}$ & $\begin{array}{l}\text { Verken } \\
\text { eller }\end{array}$ & $\begin{array}{l}\text { Delvis } \\
\text { enig }\end{array}$ & Enig & $\begin{array}{l}\text { Helt } \\
\text { enig }\end{array}$ \\
\hline $\begin{array}{l}\text { Mitt liv er på } \\
\text { mange matter nær } \\
\text { det som er } \\
\text { idealet for meg }\end{array}$ & 0 & 0 & 0 & 0 & 0 & 0 & 0 \\
\hline $\begin{array}{l}\text { Mine livsforthold } \\
\text { er veldig gode }\end{array}$ & 0 & 0 & 0 & 0 & 0 & 0 & 0 \\
\hline $\begin{array}{l}\text { Jeg er tilfreds } \\
\text { med livet mitt }\end{array}$ & 0 & 0 & 0 & 0 & 0 & 0 & 0 \\
\hline 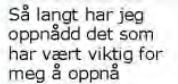 & 0 & 0 & 0 & 0 & 0 & 0 & 0 \\
\hline
\end{tabular}

file:///CI/.../AppData/Local/Microsoft/Windows/Temporary Internet Files/Content.Outlook/QGZM3EsT/Webspørreskjema (3).htm[18.04.2012 11:58:09] 


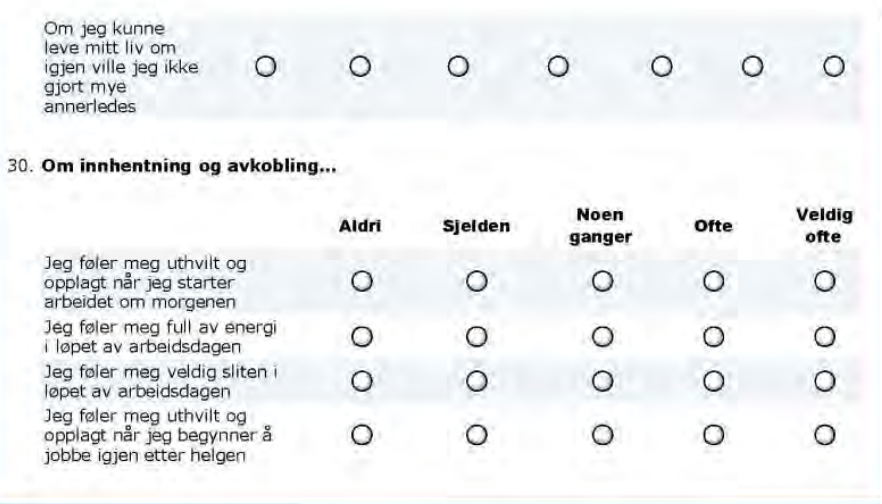

[1

Medarbeiderundersøkelse om arbeid og helse

Helse

31. Hvor mange ganger i lopet av de siste 12 månedene har du sammenlagt vært borte fra (sykemelding, behandling eller undersokelse)?

OAldri

Ó́n gang

O2-5 ganger

OMer enn 5 ganger

32. Hvor mange dager - cirka - har du vært fraværende pă grunn av sykdom de siste 12 månedene?

33. Har det under de siste 12 mănedene hendt at du har gâtt pă arbeidet, pâ tross av din helsetilstand, når du egentlig burde ha sykmeldt deg?

OAldri

OÉn gang

$\mathrm{O} 2-5$ ganger

OMer enn 5 ganger

OIkke aktuelt/Har ikke vært syk

file:///CI/.../AppData/Local/Microsoft/Windows/Temporary Internet Files/Content.Outlock/QGZM3EST/Webspørreskjema (3).htm[18.04.2012 11:58:09] 


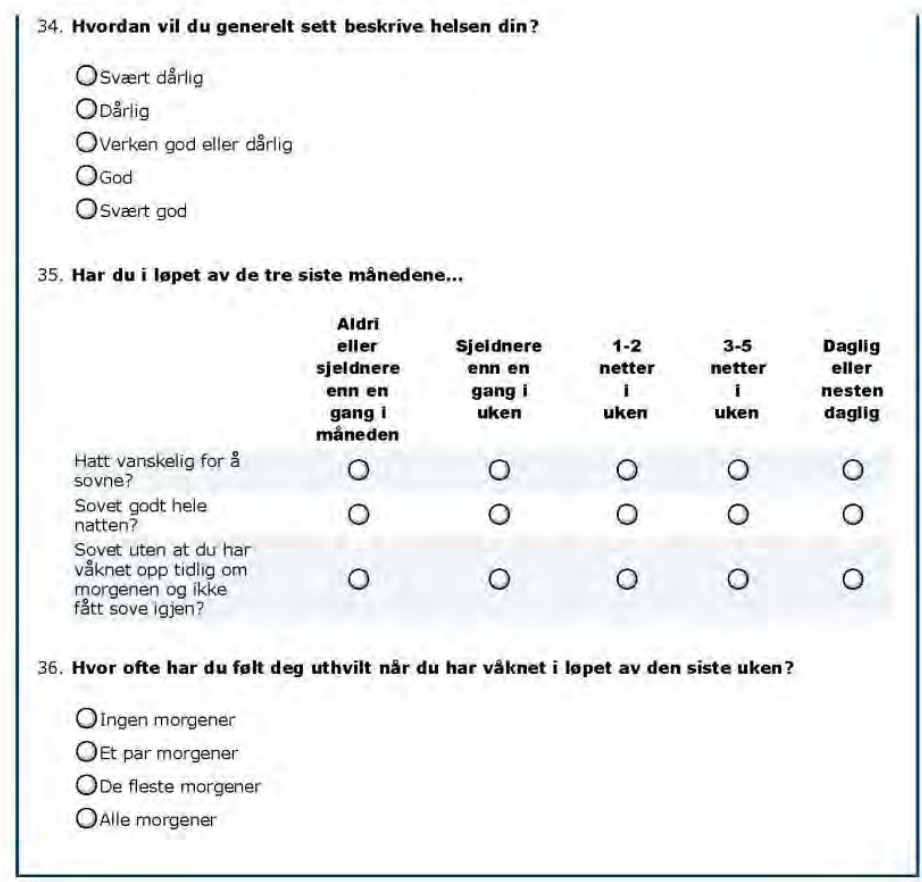

[

Medarbeiderundersøkelse om arbeid og helse

\begin{tabular}{|c|c|c|c|c|c|}
\hline \multirow{2}{*}{ 37. Om prestasjon } & & & & & ge 10 \\
\hline & $\begin{array}{c}\text { Helt } \\
\text { uenig }\end{array}$ & Uenig & Både/og & Enig & $\begin{array}{l}\text { Helt } \\
\text { enig }\end{array}$ \\
\hline $\begin{array}{l}\text { Jeg har kompetanse innenfor } \\
\text { alle delområder i mitt arbeid }\end{array}$ & 0 & 0 & 0 & 0 & 0 \\
\hline $\begin{array}{l}\text { Jeg er kompetent innenfor } \\
\text { alle arbeidets ulike } \\
\text { delomrăder og utfører mine } \\
\text { arbeidsoppgaver med } \\
\text { yrkeskyndighet } \\
\text { Jeg gior det bra i arbeidet }\end{array}$ & 0 & 0 & 0 & 0 & 0 \\
\hline
\end{tabular}

file:///CI/.../AppData/Local/Microsoft/Windows/Temporary Internet Files/Content.Outlook/QGZM3EST/Webspørreskjema (3).htm[18.04.2012 11:58:09] 


\begin{tabular}{|c|c|c|c|c|c|}
\hline $\begin{array}{l}\text { mitt som helhet, ved å utføre } \\
\text { arbeidet som forventet }\end{array}$ & 0 & 0 & 0 & 0 & \\
\hline $\begin{array}{l}\text { Jeg melder meg frivillig til å } \\
\text { gjore ting som formelt ikke } \\
\text { er păkrevd i mitt arbeid }\end{array}$ & 0 & 0 & 0 & 0 & \\
\hline $\begin{array}{l}\text { Jeg kommer med innovative } \\
\text { forslag for å forbedre den } \\
\text { generelle kvaliteten på vår } \\
\text { arbeidsplass }\end{array}$ & 0 & 0 & 0 & 0 & \\
\hline $\begin{array}{l}\text { Jeg hjelper andre hivis deres } \\
\text { arbeidsmengde øker, til de } \\
\text { har kommet over det verste }\end{array}$ & 0 & 0 & 0 & 0 & \\
\hline $\begin{array}{l}\text { Jeg hjelper mine kollegaer } \\
\text { med deres arbeidsoppgaver }\end{array}$ & 0 & 0 & 0 & 0 & \\
\hline \multicolumn{6}{|c|}{$\begin{array}{l}\text { Har du andre kommentarer eller synspunkter som du synes det er viktig a fă fram, } \\
\text { du skrive i feltet under. }\end{array}$} \\
\hline
\end{tabular}

file:///CI/.../AppData/Local/Microsoft/Windows/Temporary Internet Files/Content.Outlook/QGZM3EsT/Webspørreskjema (3).htm[18.04.2012 11:58:09] 


\section{Building engagement and healthy organisations}

The main aim of the project was to investigate the predictors of positive work-related states and attitudes, e.g. work engagement, meaning at work and personal growth, and healthy organisations. A questionnaire on these positive factors at work were pilot-tested through a data collection in chosen companies in Norway and Sweden. The results of these studies were used as a base for a preliminary validation of the Nordic Questionnaire on Positive Organisational Psychology (N-POP) published in this report. It is concluded that the N-POP constitutes a reliable and valid instrument. The concluding summary suggests that the concepts of work environment, health and productivity do indeed seem able to flow together to reach an optimal point at which wellbeing at the individual level is coexistent with efficient and productive work organisations.

CONTRIBUtors AND MEMBERS OF THE NORDIC RESEARCH GROUP

Norway Marit Christensen

Lisa Vivoll Straume

Department of Psychology, Norwegian University of Science and Technology (NTNU), Trondheim

Denmark Vilhelm Borg

Thomas Clausen

National Research Centre for the Working Environment

(NRCWE), Copenhagen

Finland Jari Hakanen

Finnish Institute of Occupational Health, Helsinki

Sweden Gunnar Aronsson

Johan Guthenberg

Department of Psychology, Stockholm University, Stockholm

Ulrika Lundberg

Department of Sociology and Work Science, University of Gothenburg, Gothenburg 